\title{
Recruiting Terrorism Informants: The Problems with Immigration Incentives and the S-6 Visa
}

\author{
Emily Stabile*
}

Since the FBI's post-9/11 establishment of a preventative stance toward terrorism has increased the need for intelligence, the agency has turned to the increased use of immigration law to recruit additional confidential informants. Using the threat of immigration consequences-particularly deportation-to produce terrorism intelligence presents novel problems for both the intelligence gathering process and the informants. Informants recruited in this manner who also lack established ties to foreign terrorist organizations have an enormous incentive to fabricate information to fulfill their end of the agreement and avoid deportation. Recruiting informants via immigration law also affords less protection than recruiting them by offering monetary rewards or reductions in sentencing. Furthermore, the FBI's recruitment tactics encourage ethnic and religious profiling, alienating Muslim and Middle Eastern communities. Although Congress created the S-6 visa classification specifically to induce cooperation from informants in terrorism investigations, the visa is rarely used due to its stringent eligibility requirements for informants. In order for law enforcement to successfully use the S-6 visa program and to encourage the trust of and cooperation from informants, legislative overhaul is needed. An S-6 visa program that emphasizes pre-existing ties to terrorist organizations, increases the availability of S-6 visas, and lowers the barriers to the visas' use will produce counterterrorism intelligence that is more reliable and actionable and provide greater protection for civil liberties and to informants themselves.

Copyright (C) 2014 California Law Review, Inc. California Law Review, Inc. (CLR) is a California nonprofit corporation. CLR and the authors are solely responsible for the content of their publications.

* J.D., University of California, Berkeley, School of Law, 2013. For their encouragement and guidance with this Comment, I wish to thank Kate Jastram, John Yoo, Eleanor Swift, Saira Mohamed, Allie Hartry, and the members of the California Law Review that helped bring this Comment into being. I would also like to thank my parents, as well as the rest of my family without whom all of this would not have been possible. Finally, I owe a thank you to Erin Dummer for her support. 
Introduction. 236

I. Background: Traditional Informant Use Versus Modern Use in Terrorism Investigations

II. Problems with Recruiting Informants Based on Immigrant Status ..... 246

A. Mosque Surveillance Chills Free Speech ........................................ 246

B. Mosque Surveillance Encourages Religious and Ethnic Profiling.. 249

C. Terrorism Informants' Presence in Muslim and Middle Eastern

Communities Damages Intelligence Efforts ................................. 251

D. Indiscriminate Use of Informants Leads to Entrapment .................. 255

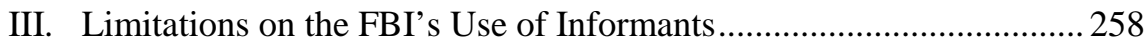

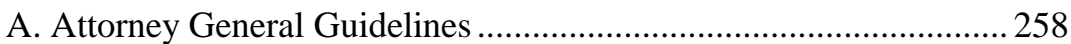

B. Constitutional Limitations ............................................................. 260

C. Entrapment Defense and Outrageous Government Conduct

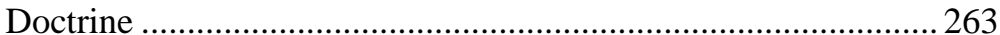

D. Nondeportation Agreements in Plea Bargains................................. 265

IV. A Possible Solution: The S-6 Visa .....................................................2. 267

A. The Current S-6 Visa Requirements ................................................ 268

B. Proposed Modifications to the S-6 Visa ........................................... 271

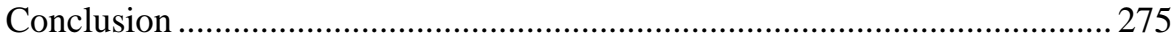

\section{INTRODUCTION}

In 2004, the FBI approached Imam Foad Farahi, a cleric at a mosque in South Florida, and promised him lawful permanent resident status ${ }^{1}$ in return for information on members of his South Florida Muslim community. ${ }^{2}$ Farahi had entered the United States on a student visa that had since expired, and was at the time applying for political asylum. ${ }^{3}$ When Farahi refused the FBI's offer and told the agents that he had no information beyond his mere acquaintance with the individuals sought by the agents, the FBI agents threatened to deport Farahi to Iran and charge him with providing material support to terrorism unless he cooperated by acting as an informant. ${ }^{4}$

Because the FBI's post-9/11 establishment of a preventative stance towards terrorism ${ }^{5}$ has increased the need for intelligence, ${ }^{6}$ the agency has

1. Lawful permanent residency would grant Farahi legal recognition in the United States. See 8 U.S.C. § 1101 (2012).

2. Trevor Aaronson, FBI Tries to Deport Muslim Man for Refusing to Be an Informant, MIAMI NEW TIMES (Oct. 8, 2009), http://www.miaminewtimes.com/2009-10-08/news/unholy-war-fbi-triesto-deport-north-miami-beach-imam-foad-farahi-for-refusing-to-be-an-informant/.

3. Id.

4. Although Farahi had inherited Iranian citizenship from his father, he grew up in Kuwait and had never been to Iran.

5. There is no internationally agreed upon definition of terrorism. See Ben Golder \& George Williams, What Is 'Terrorism'? Problems of Legal Definition, 27 UNSW L.J. 270 (2004). Recently, in the United States, the PATRIOT Act defined "international terrorism" as actions that: 
turned to the increased use of immigration law and residence status to recruit more confidential informants. ${ }^{7}$ Although the FBI does not comment on its informant recruitment methods, ${ }^{8}$ numerous stories similar to Farahi's have been reported since $9 / 11 .^{9}$ In fact, allegations of the FBI's aggressive use of past

(A) involve violent acts or acts dangerous to human life that are a violation of the criminal laws of the United States or of any State, or that would be a criminal violation if committed within the jurisdiction of the United States or of any State;

(B) appear to be intended-

(i) to intimidate or coerce a civilian population;

(ii) to influence the policy of a government by intimidation or coercion; or

(iii) to affect the conduct of a government by mass destruction, assassination, or kidnapping; and

(C) occur primarily outside the territorial jurisdiction of the United States, or transcend national boundaries in terms of the means by which they are accomplished, the persons they appear intended to intimidate or coerce, or the locale in which their perpetrators operate or seek asylum.

18 U.S.C. § 2331(1) (2012).

6. See The State of Intelligence Reform 10 Years After 9/11: Hearing Before the H. Perm. Select Comm. on Intelligence (Oct. 6, 2011) (statement of Robert Mueller, Dir. Fed. Bureau of Investigation), available at http://www.fbi.gov/news/testimony/the-state-of-intelligence-reform-10years-after-911; Memorandum from Att’y Gen. John Ashcroft to All United States Attorneys, AntiTerrorism Plan (Sept. 17, 2001), www.justice.gov/ag/readingroom/ag-091701.pdf.

7. The definition of informant, which the FBI officially refers to as a "confidential human source," includes:

[A]ny individual who is believed to be providing useful and credible information to the FBI for any authorized information collection activity, and from whom the law enforcement agency expects or intends to obtain additional useful and credible information in the future, and whose identity, information, or relationship with the FBI warrants confidential handling.

U.S. Dep'T OF Justice, The AtToRney General's Guidelines Regarding the UsE of FBI CONFIDENTIAL HUMAN SOURCES 4, (2006), available at www.justice.gov/oip/docs/ag-guidelinesuse-of-fbi-chs.pdf [hereinafter ATTORNEY GEN. CONFIDENTIAL SOURCES GUIDELINES]; see also Confidential Informant Accountability Act of 2013, H.R. 265, 113th Cong. (2013).

8. See Trevor Aaronson, The Informants, MotHER JonES, Sept.-Oct. 2011, at 30, 37 [hereinafter The Informants] ("Officially, the FBI denies it blackmails informants. 'We are prohibited from using threats or coercion,' says Kathleen Wright, an FBI spokeswoman. (She acknowledges that the bureau has prevented helpful informants from being deported.)").

9. See Aaronson, supra note 2. For example, Yassine Ouassif was asked to become an informant by the FBI in Oakland, California in 2005. The FBI confiscated his green card and threatened to deport him to Morocco if he failed to cooperate. Ouassif later won his deportation case. Similarly, Tarek Mehanna, who was convicted of material support in 2012 and is currently serving a seventeen-and-a-half-year sentence, alleges that the case is an attempt to deport him in retaliation for not cooperating with the FBI as an informant. Ahmadullah Sais Niazi, a naturalized citizen from Afghanistan, also claims that he was charged with making false statements in his citizenship application as retaliation for refusing to act as an informant. Id.; see also CITY AND COUNTY OF SAN FRANCISCO HUMAN RIGHTS COMMISSION, COMMUNITY CONCERNS OF SURVEILLANCE, RACIAL AND RELIGIOUS PROFILING OF ARAB, MidDle EASTERN, MuSLIM, AND SOUTH ASIAN COMMUNITIES AND POTENTIAL REACTIVATION OF SFPD INTELLIGENCE GATHERING (2011) [hereinafter SF HuMAN RIGHTS COMMISSION], available at http://www.sf-hrc.org/modules/showdocument.aspx?documentid =983. At a September 2010 San Francisco Human Rights Commission hearing, civil rights attorney and activist Wazhma Mojaddidi provided written testimony from two of her clients. One wrote:

My adult son had a green card application pending when I was contacted by the FBI .... The agents told me if I wanted my son to get the green card then I needed to become an informant for the FBI. I told them I would think about it. They arranged another meeting ... I told them at that time that I didn't want to become an informant. They then told me that if I did not agree to becoming an informant that they would prevent my son 
violations of immigration laws to pressure individuals whom the agency believes may have terrorism knowledge have repeatedly surfaced. ${ }^{10}$

The Informants, a yearlong investigation into the FBI's use of informants, led by Trevor Aaronson and the University of California at Berkeley's Reporting Program in conjunction with Mother Jones, details the FBI's expanded use of informants in terrorism investigations. ${ }^{11}$ Of the approximately five hundred federal terrorism prosecutions conducted since 9/11, about half used an informant, ${ }^{12}$ and forty-nine of them were the result of work done by agent provocateurs. ${ }^{13}$ Aaronson's investigation also shed light on the FBI's use of immigration law and the threat of deportation to incentivize informants to cooperate. ${ }^{14}$ Aaronson explains,

A typical scenario will play out like this: An FBI agent trying to get someone to cooperate will look for evidence that the person has immigration troubles. If they do, he can ask [Immigration and Customs Enforcement (ICE)] to begin or expedite deportation proceedings. If the immigrant then chooses to cooperate, the FBI will tell the court that he is a valuable asset, averting deportation. ${ }^{15}$

from receiving his green card. Now, years later, my son is still waiting for his green card. He should have received it; but the reason he has not received it is his case is caught up in 'security clearances.' There's no reason why my son's case should be delayed. I believe that the FBI is punishing my son because I refused to become an informant for the FBI.

The other client wrote:

While I was waiting for a decision to be made [on my naturalization application] two FBI agents visited me. They told me that they could arrange for my application to be quickly processed if I became an informant. I told them I was not interested. Soon after their visit I received notice that my application was denied because the government claimed I did not have 'good moral character' because of a small tax error in one of my tax filings that I had already cleared with the IRS. My attorney filed another lawsuit in federal court; after I testified in a deposition about my experience with the five year delay, the visit from the FBI agents and my impeccable moral character, the U.S. Attorney agreed to grant my naturalization and my case was dismissed in court.

SF HUMAN RigHTS COMMISSION, supra at 21-22.

10. See, e.g., STEPHEN DOWNS, PROJECT SALAM, VICTIMS OF AMERICA's DiRTY WARs 41, 48, 50 (2011), available at www.projectsalam.org/downloads/Victims_of_Americas_Dirty_Wars.pdf; Aaronson, supra note 2; Jeffrey Kaye, ICE Uses Threats of Deportation To Produce Terrorism 'Intel,' THE PUBLIC RECORD (Feb. 19, 2010), http://pubrecord.org/nation/6996/threats-deportation-produceterrorism/; FBI Arrests Afghan Accused of al-Qaida Links, NBCNEWS.COM (Feb. 21, 2009), http://www.msnbc.msn.com/id/29311236/ns/us_news-security/t/fbi-arrests-afghan-accused-al-qaidalinks/\#.Tq2mHXF7rhM. SALAM stands for Support and Legal Advocacy for Muslims.

11. The Informants, supra note 8.

12. Id. at 32 ("Nearly half the prosecutions involved the use of informants, many of them incentivized by money (operatives can be paid as much as $\$ 100,000$ per assignment) or the need to work off criminal or immigration violations.”).

13. Id. (Of the approximately 500 prosecutions, "[s]ting operations resulted in prosecutions against 158 defendants. Of that total, 49 defendants participated in plots led by an agent provocateuran FBI operative instigating terrorist action.”). An agent provocateur, or informant, is an agent of law enforcement "employed . . . to induce or incite others to violence or illegal acts, in order to secure an arrest, discredit a cause, etc.” Agent Provocateur Definition, OED.COM, http:/www.oed.com/view/ Entry/3864 (last visited Oct. 18, 2013).

14. The Informants, supra note 8 , at 32 .

15. Id. at 36 . 
Using the threat of immigration consequences like deportation to produce terrorism intelligence presents novel problems for the intelligence gathering process and the informants. When individuals are pressured into becoming informants by the threat of deportation, which may remove them from their family and all sources of support, the decision essentially becomes a Hobson's choice. ${ }^{16}$ Informants recruited in this manner who also lack legitimate ties to foreign terrorist organizations ${ }^{17}$ have an enormous incentive to fabricate information to fulfill their end of the agreement and avoid deportation. ${ }^{18}$ Attorney Stephen Downs of Project SALAM explained,

Community life is shattered as the government often forces Muslim immigrants to spy on their own communities or give false testimony with the threat that the Muslim's immigration status will be "revised" if the Muslims do not cooperate. Such practices generate fear and alienation in the Muslim community and diminish our security rather than enhance it. ${ }^{19}$

As Downs notes, the intelligence these informants provide can be unreliable, ${ }^{20}$ because these individuals may feel they must offer up something to the government to avoid being removed from their families, jobs, and lives. The threat of false intelligence is grave. In addition to the possibility of entrapment ${ }^{21}$ by agent provocateurs, false intelligence may encourage ethnic and religious profiling of Muslim and Middle Eastern communities, ${ }^{22}$ chill free speech, $^{23}$ and waste finite intelligence resources. Recruitment through

16. A Hobson's choice has the appearance of a choice when in reality there is only one option. See Choice Definition, OED.COM, http://www.oed.com/view/Entry/32111 (last visited Oct. 18, 2013).

17. For the definition and identification of various "foreign terrorist organizations" from the Department of State, see Foreign Terrorist Organizations, U.S. DEP’T OF STATE (Sept. 28, 2012), http://www.state.gov/j/ct/rls/other/des/123085.htm.

18. See JOHN MADINGER, CONFIDENTIAL INFORMANT: LAW ENFORCEMENT'S MOST VALUABLE TOOL 51 (2000) ("Fear is a powerful emotion and an effective motivator .... People who become informants out of fear generally do so because they are threatened by either the law or other criminals.").

19. SF HUMAN RightS COMMISSION, supra note 9, at 33.

20. Downs, supra note 10.

21. Entrapment occurs when enforcement agents induce a person to commit a crime he or she would not otherwise have committed. See ALEXANDRA NATAPOFF, SNITCHING: CRIMINAL INFORMANTS AND THE EROSION OF AMERICAN JUSTICE 67-73 (2009); Wadie E. Said, The Terrorist Informant, 85 WASH. L. REV. 687, 715-33 (2010).

22. Throughout this Comment, I use the terms "Muslim communities" and "Middle Eastern communities" to refer to the groups most impacted by the federal government's post-9/11 policies, but affected populations may also include Sikhs, South Asians, Arabs, and others perceived as members of these groups. Occasionally these groups are also referred to as the AMEMSA communities: Arab, Middle Eastern, Muslim, and South Asian.

23. See, e.g., David A. Harris, Law Enforcement and Intelligence Gathering in Muslim and Immigrant Communities After 9/11, 34 N.Y.U. REV. L. \& SoC. CHANGE 123 (2010); Murad Hussain, Defending the Faithful: Speaking the Language of Group Harm in Free Exercise Challenges to Counterterrorism Profiling, 117 YALE L.J. 920 (2008); Jerry Markon, Lawsuit Alleges FBI Violated Muslims' Freedom of Religion, WASH. POST (Feb. 22, 2011, 10:45 PM), http://www.washingtonpost .com/wp-dyn/content/article/2011/02/22/AR2011022206987.html. 
immigration law also affords less protection to informants than recruitment done by offering monetary rewards or reductions in sentencing. ${ }^{24}$ For example, unlike criminal offenses, there is no statute of limitations governing civil penalties like deportation, removal, or exclusion orders, which means that the FBI can use immigration violations to leverage cooperation from out-of-status individuals who have been in the country for years. Moreover, unlike an informant who is promised a sentence reduction or lessened charges and who can enforce his or her bargain with the government through plea bargaining, an informant promised immigration benefits has no way of enforcing these promises. ${ }^{25}$ Furthermore, the Sixth Amendment's guarantee of counsel ${ }^{26}$ does not apply to immigration violations. ${ }^{27}$ Finally, according to some reported cases, the government has failed to reward informants with the promised immigration benefits after receiving their cooperation. ${ }^{28}$

With fewer bargaining options, less protection, and potentially more to $\operatorname{lose}^{29}$ than informants recruited through monetary incentives or promises of sentence reductions, there is greater incentive for informants "flipped" ${ }^{30}$ via

24. Mary Beth Sheridan, Immigration Law as an Anti Terrorism Tool, WASH. POST, June 13, 2005, at A1.

Authorities say they sometimes turn to immigration charges rather than terrorism charges because a case might be based on classified information that they cannot reveal in court without damaging other investigations. Sometimes they face other legal barriers .... Immigration lawyers have raised concerns about using [immigration] courts in terrorismrelated cases, because they provide fewer legal protections for the accused. For example, those charged do not have the right to an attorney, and they may be detained even after a judge has ordered them freed on bond. "There's no key to the jailhouse door when Immigration’s got you,” said Malea Kiblan, an immigration lawyer in Northern Virginia.

Id.

25. One novel argument suggests institutional ratification of contracts as a way for informants to enforce their immigration bargains with the government. See Colleen Melody, Trading Information for Safety: Immigrant Informants, Federal Law-Enforcement Agents, and the Viability of NonDeportation Agreements, 83 WASH. L. REV. 599 (2008).

26. Gideon v. Wainwright, 372 U.S. 355 (1963) (holding that the Sixth Amendment requires the government to provide indigent criminal defendants with counsel).

27. See Lara-Torres v. Ashcroft, 383 F.3d 968, 973 (9th Cir. 2004) (concluding that "because deportation and removal proceedings are civil, they are 'not subject to the full panoply of procedural safeguards accompanying criminal trials' including the right to counsel under the Sixth Amendment”) (quoting Magallanes-Damian v. INS, 783 F.2d 931, 933 (9th Cir. 1986)).

28. See, e.g., Awad v. United States, 301 F.3d 1367 (Fed. Cir. 2002); Andrew Becker, 'USED, ABUSED AND TOSSED'; Despite Aid to U.S. Law Enforcement, Some Informants Face Deportation, L.A. TIMES, Feb. 12, 2010, at AA1; Helen O'Neill, Informants for Feds Face Deportation, NBCNEWS.COM (Feb. 13, 2010), http://www.msnbc.msn.com/id/35383376/ns/us_news-life/t/ informants-feds-face-deportation/\#.TrIIo3F7rhM; Anna Werner, California Terror Informant Faces Deportation, CBS5.COM (June 30, 2009), available at http://www.actforamerica.org/index.php/learn /recent-news/10-newsmaster/1378-california-terror-informant-faces-deportation; see generally Joaquin J. Alemany, Comment, United States Contracts with Informants: An Illusory Promise?, 33 U. MIAMI INTER-AM. L. REV. 251 (2002).

29. Deportation permanently uproots an individual from work and family, often sending him or her back to a country that he or she has little connection with.

30. "Flipping" is the law enforcement term used to describe the situation wherein an offender agrees to become an informant in return for whatever incentive the law enforcement officer offers. Here, the offender would likely be an out-of-status immigrant, and the FBI's offer would be to either 
immigration violations to provide unreliable information. Furthermore, due to the latitude afforded to the executive branch in national security matters, there is a darker veil of secrecy shrouding measures for recruiting terrorism informants than for other types of informants. ${ }^{31}$ Immigration status offers a valuable way for the FBI to elicit cooperation and collect intelligence from individuals who otherwise would not be forthcoming. However, this method for collecting intelligence can prove counterproductive when indiscriminately applied to situations where the informants lack useful connections to terrorist groups. Decreased intelligence benefits, lack of protection for informants, and increased ethnic and religious profiling suggest that changes to how the FBI recruits terrorism informants with immigration threats and rewards are needed.

While the FBI appears to recruit most terrorism informants through informal means, an existing visa program already formally offers immigration benefits to informants in exchange for their cooperation with terrorism investigations. As part of the Violent Crime Control and Law Enforcement Act of $1994,{ }^{32}$ Congress specifically designed the S-6 visa to attract and reward immigrants who were willing to cooperate by giving terrorism intelligence. ${ }^{33}$ However, given the small number of S-6 visas issued, the program likely fails to meet the FBI's intelligence recruitment needs.

The fifty allotted S-6 visas per year ${ }^{34}$ do not match up with the number of informants (fifteen thousand) used by the FBI. ${ }^{35}$ In order to qualify for the S-6 visa, an informant must also meet the eligibility requirements of the Department of Justice's Rewards for Justice Program, a separate program designed to elicit and monetarily reward terrorism intelligence. ${ }^{36}$ Lastly, access to the S-6 visa is further restricted by the requirement that the informant be subject to danger if he or she is returned to his or her home country. ${ }^{37}$ Since the FBI has long used immigration law as an incentive to compel terrorism informants to act, it has little motivation to use a rewards program that presents additional barriers. The stringent eligibility requirements to obtain an S-6 visa explain its ongoing underuse. ${ }^{38}$

overlook or correct the immigrant's status for his or her cooperation. See, e.g., ETHAN A. NADELMANN, COPS ACROSS BORDERS: THE INTERNATIONALIZATION OF U.S. CRIMINAL LAW ENFORCEMENT 215 (1993).

31. NATAPOFF, supra note 21, at 168-69.

32. 8 U.S.C. § 1101(a)(15)(S) (2012).

33. Karma Ester, Cong. Research SERV., RS21043, IMMigration: S VISAS FOR CRIMINAL AND TERRORIST INFORMANTS (2005).

34. The Department of Homeland Security allows fifty S-6 visas to be issued per year, but the available numbers show that only a fraction of these are actually used. Id. at 3. By contrast, the FBI's informants reportedly number in the thousands. See The Informants, supra note 8.

35. See Aaronson, supra note 2.

36. Rewards for Justice Program, U.S. DEP'T OF STATE, http://www.state.gov/m/ds/terrorism/ c8651.htm (last visited Oct. 18, 2013).

37. 8 U.S.C. § 1101(a)(15)(S)(ii)(III).

38. ESTER, supra note 33, at 2 (stating that no S-6 visas were issued during the years 19962005). 
This Comment proposes the S-6 visa requirements should be modified in a way that encourages trust and cooperation from informants by allowing informants to enforce their bargains with the FBI. A legislative overhaul that emphasizes pre-existing ties to terrorist organizations, increases the number of available visas, and lowers the barriers to the S-6 visa's use would produce more reliable and actionable intelligence, and provide greater protection for the informants' civil liberties and free speech. Congressional oversight of the FBI's use of S-6 visas would also provide a valuable check on the FBI's largely unlimited control over terrorism informants.

Part I examines the differences between the FBI's historical use of informants in investigating crimes such as drug smuggling and prostitution and the FBI's current use of informants investigating terrorism. Part II discusses how the use of immigration law to recruit informants, as well as the presence of informants in Muslim and Middle Eastern communities, chills free speech and encourages religious and ethnic profiling. Part II also addresses how the FBI's use of immigration law to recruit terrorism informants heightens the risk of false intelligence and increases the possibility of entrapment and prosecution of individuals who do not pose a true threat. Part III looks at limitations of the FBI's recruitment and use of informants, and analyzes the failure to protect informants from abuse by handlers and constrain the FBI's actions. Part IV explains the S-6 visa requirements and advises increasing the congressional allotment of S-6 visas and modifying the eligibility requirements to improve their efficacy in terrorism investigations. Finally, Part V concludes that a modified S-6 visa program will result in better relationships between law enforcement and the Muslim and Middle Eastern communities, less encroachment on civil rights, and ultimately, more effective counterterrorism investigations and prosecutions.

I.

\section{BACKGROUND: TRADITIONAL INFORMANT USE VERSUS MODERN USE IN TERRORISM INVESTIGATIONS}

Despite the FBI's long history of problematic relationships with informants, ${ }^{39}$ both Congress and the Department of Justice-the FBI's parent agency-provide very little oversight of FBI informants. The lack of transparency, control, and accountability give the FBI almost unlimited power over how it recruits, handles, and rewards informants. ${ }^{40}$ In particular, because of the greater secrecy afforded to national security investigations, the use of terrorism informants presents unique problems not present in traditional, nonterrorism use of informants.

39. Amanda J. Schreiber, Dealing with the Devil: An Examination of the FBI's Troubled Relationship with Its Confidential Informants, 34 COLUM. J.L. \& SOC. PROBS. 301 (2001).

40. See NATAPOFF, supra note 21, at 97-99 (discussing the FBI's resistance to public transparency and legislative oversight in regard to informant practices). 
The use of informants in terrorism investigations differs in several ways from their use in the investigation of domestic crimes like smuggling, prostitution, and financial impropriety. Although the FBI has been using informants to conduct investigations since the agency's inception, ${ }^{41}$ informants were traditionally used to investigate "victimless" crimes such as white-collar crimes $^{42}$ and crimes dealing with prostitution, drugs, and corruption. ${ }^{43}$ Informants proved especially useful in those cases because all parties to the crime were usually guilty and not likely to inform authorities, making it difficult for law enforcement agents to discover the crime on their own. ${ }^{44}$ Consequently, because individuals already part of the criminal organization or conspiracy had the trust and confidence of the organization and could provide the most useful information to law enforcement over a longer period of time, the FBI has generally recruited informants in these investigations from the inside. The FBI's “Top Echelon” informant program, for example, sought to recruit high-ranking members of the mafia as informants. ${ }^{45}$ Notably, however, even the FBI's traditional method of recruiting informants from within the criminal organizations resulted in false intelligence and botched cases. ${ }^{46}$

While there are no detailed studies on the differences between terrorism informants and traditional informants because the FBI keeps most of this information confidential, ${ }^{47}$ broad observations can still be made. First, the FBI's preventative stance on terrorism has significantly increased reliance on informants' intelligence. ${ }^{48}$ After 9/11, the FBI drastically expanded the use of

41. See United States v. Dennis, 183 F.2d 201, 224 (2d Cir. 1950) (“Courts have countenanced the use of informers from time immemorial; in cases of conspiracy, or in other cases when the crime consists of preparing for another crime, it is usually necessary to rely upon them or upon accomplices because criminals will almost certainly proceed covertly.”); Harris, supra note 23, at 156 (“[A]mong all of the government's illegal spying tactics, '[t]he most pervasive surveillance technique [was] the informant. In a random sample of domestic intelligence cases, $83 \%$ involved informants ....”') (quoting SELECT COMM. TO STUDY GOVERNMENTAL OPERATIONS WITH RESPECT TO INTELLIGENCE ACtivities, 94TH Cong., Intelligence Activities AND tHe Rights of AMERICANS 13 (Comm. Print 1976)).

42. NATAPOFF, supra note 21, at 152.

43. Schreiber, supra note 39, at 301-02.

44. Id. at 302; MADINGER, supra note 18, at 26.

45. U.S. Dep'T of Justice OfFice of the Inspector Gen., The Federal Bureau of INVESTIGATION'S COMPLIANCE WITH THE ATTORNEY GENERAL'S INVESTIGATIVE GUIDELINES 6465 (2005) [hereinafter INSPECTOR GEN. COMPLIANCE STUDY] ("The FBI's Top Echelon Criminal Informant Program was established in 1961 when FBI Director J. Edgar Hoover instructed all Special Agents in Charge (SACs) to 'develop particularly qualified, live sources within the upper echelon of the organized hoodlum element who will be capable of furnishing the quality information' needed to attack organized crime.”); see also Daniel V. Ward, Note, Confidential Informants in National Security Investigations, 47 B.C. L. REV. 627, 636 (2006).

46. See Schreiber, supra note 39.

47. See NATAPOFF, supra note 21, at 171.

48. After 9/11, the FBI shifted its focus from prosecuting and punishing crimes already committed to gathering intelligence and preventing terrorist acts before they occurred. See During FBI's Mueller Era, 9/11 Elevated Priority of Intelligence and Prevention, PBS NEWSHOUR (Aug. 1, 2013), http://www.pbs.org/newshour/bb/nation/july-dec13/mueller_08-01.html; see also Norman C. 
informants ${ }^{49}$ from around 1,500 in $1975^{50}$ to an estimated 15,000 today. ${ }^{51}$ Informants have become the number one tool for preventing terrorist acts. ${ }^{52}$

Second, law enforcement dealings with terrorism informants receive greater deference from courts and other limiting actors because terrorism is considered a national security matter instead of simply a domestic law enforcement matter. ${ }^{53}$ The executive branch has greater control over national security and foreign intelligence matters than over domestic law enforcement, an area traditionally reserved to the states. ${ }^{54}$ Thus, the post-9/11 characterization of terrorism as a national security matter results in courts affording more leeway to terrorism investigations than domestic criminal investigations. ${ }^{55}$ In other words, the federal government is afforded more secrecy in matters of national security. ${ }^{56}$ Hence, because the government can invoke national security concerns to keep information about the informant and handler privileged, there is less regulation governing the recruitment and handling of terrorism informants than traditional criminal informants. ${ }^{57}$

Bay, Executive Power and the War on Terror, 83 DENV. U. L. REV. 335, 359-60 (2005); Said, supra note 21, at 715 .

49. The Informants, supra note 8, at 32 ("After years of emphasizing informant recruiting as a key task for its agents, the FBI now maintains a roster of 15,000 spies-many of them tasked, as Hussain was, with infiltrating Muslim communities in the United States. In addition, for every informant officially listed in the bureau's records, there are as many as three unofficial ones, according to one former high-level FBI official, known in bureau parlance as 'hip pockets.'”).

50. Id. A 1975 Senate oversight committee found the FBI had 1,500 informants. Id. In 1980, officials disclosed there were 2,800 informants. Id. Six years later, the Los Angeles Times reported the number of bureau informants had ballooned to 6,000 following the FBI's push into drugs and organized crime. Id.

51. Terror Probes Have FBI's Informant Numbers Soaring, NPR (Aug. 21, 2011, 5:10 PM), http://www.npr.org/2011/08/21/139836377/the-surge-in-fbi-informants; see also The Informants, supra note 8, at 32 ("Ever since 9/11, counterterrorism has been the FBI's No. 1 priority, consuming the lion's share of its budget $-\$ 3.3$ billion, compared to $\$ 2.6$ billion for organized crime-and much of the attention of field agents and a massive, nationwide network of informants .... [T] he bureau now maintains a roster of 15,000 spies.”).

52. See The Informants, supra note 8.

53. NATAPOFF, supra note 21, at 168; see also Bay, supra note 48, at 339 (discussing how domestic law enforcement was reframed as a military and national security issue after 9/11).

54. Bay, supra note 48, at 339-40, 346-47.

55. Id. at 369 (“ $[\mathrm{C}]$ haracterizing terrorism as a military issue, rather than a law enforcement problem, has the inexorable consequence of expanding the scope of executive discretion, unfettered from the judicial oversight inherent in the criminal justice system and the need to prove guilt beyond a reasonable doubt. For reasons grounded in separation of powers and institutional competency, courts are apt to be more deferential to the President when he acts as Commander-in-Chief, than when he acts as a prosecutor.”).

56. Id. at 376.

57. NATAPOFF, supra note 21, at 169. For a comprehensive look at government secrecy in terrorism trials, including the use of informants, see generally SERRIN TURNER \& STEPHEN J. SCHULHOFER, THE SECRECy PROBLEM IN TERRORISM TRIALS (2005). For an analysis of how several major statutes and their attendant judicial interpretation have contributed to increased secrecy after 9/11, see Sidney A. Shapiro \& Rena I. Steinzor, The People's Agent: Executive Branch Secrecy and Accountability in an Age of Terrorism, 69 LAW \& CONTEMP. PROBS. 99, 113-28 (2006). 
Third, while false and inaccurate intelligence has generally been a problem with informants, ${ }^{58}$ recent terrorism investigations raise the question of whether the alleged terrorist crimes would have occurred without law enforcement instigating the terrorist activities. ${ }^{59}$ Informants in these cases aggressively instigated the defendants' participation in the plot. ${ }^{60}$ Recruiting informants who lack ties to terrorist organizations may be at the root of this problem, because they lack predetermined targets known to be involved in terrorist groups. ${ }^{61}$ Without these targets, informants under pressure to avoid deportation or other immigration consequences, for example, are more likely to produce false information. ${ }^{62}$ Further complicating this issue, the government has suffered from credibility problems in terrorism investigations for not always fulfilling the promises made to informants. ${ }^{63}$ One FBI informant, a Yemeni citizen named Mohamed Alanssi, set himself on fire in front of the White House after alleging that the FBI had broken numerous promises to him. ${ }^{64}$ Governmental credibility is critical to maintaining a relationship of trust between law enforcement and informants, and thereby facilitates the gathering of credible intelligence.

Due to the vast number of terrorism informants today, the secrecy underlying the investigations, ${ }^{65}$ and the potential for false intelligence, the recruitment and use of informants in terrorism investigations present unique problems to the FBI. Because of increased confidentiality surrounding national security issues, the government has the means and incentives to shield the true extent of its recruitment and use of terrorism informants from courts and the public. $^{66}$ To increase accountability and lessen the risk of abuse, more oversight over the FBI's dealings with terrorism informants is needed. Notably, some limits on the FBI's use of informants do exist. However, given the

58. See NATAPOFF, supra note 21, at 69-81; Schreiber, supra note 39.

59. NATAPOFF, supra note 21, at 171-72.

60. See, e.g., Said, supra note 21, at 715-32.

61. See Jerry Markon, Mosque Infiltration Feeds Muslims’ Distrust of FBI, WASH. Post, Dec. 5, 2010, at A1 ("Law enforcement sources said that the FBI trained Monteilh and that he aided an existing investigation. Monteilh, however, said he was ordered to randomly surveil and spy on Muslims to ferret out potential terrorists.”).

62. NATAPOFF, supra note 21, at 70 (explaining that informants are unreliable "because informants have such predictable and powerful inducements to lie, because law enforcement relies heavily on their information, and because the system is not well designed to check that information. As a result, unreliable informant information permeates the process in ways that predictably lead to bad results ...."). Natapoff later writes that the problem is particularly acute in regard to terrorism informants because "[s]ome work so hard to generate cases and information that the resulting prosecutions look more like entrapment than prevention." Id. at 171.

63. Id. at $172-73$.

64. William Glaberson, Man Burned at White House Is Called Central to Terror Case, NY TiMEs, Nov. 17, 2004, at B1.

65. For a discussion on government secrecy and terrorism, see supra note 57.

66. Id. 
secrecy surrounding national security concerns, whether these limits apply in terrorism investigations remains unclear.

II.

\section{PROBLEMS WITH RECRUITING INFORMANTS BASED ON IMMIGRANT STATUS}

The FBI's use of immigration rewards and threats to recruit informants undermines civil liberties and cooperation with Muslim, Middle Eastern, and other immigrant communities. ${ }^{67}$ In general, the presence of informants in mosques and the surrounding community creates suspicion and distrust of law enforcement efforts, chilling free speech. That is, when community members know that informants are potentially monitoring their speech, community members are less likely to cooperate with law enforcement efforts. Furthermore, by sending informants into Muslim and Middle Eastern communities without specific targets to surveil, the FBI encourages ethnic and religious profiling and helps conflate Islam and terrorism in the public eye. Because informants recruited via immigration law possess less bargaining power and face potentially more serious consequences than those recruited via criminal law incentives, there is greater incentive for these informants to supply false information and accuse innocent individuals.

Ethnic and religious profiling, combined with the indiscriminate surveillance carried out by informants, can entrap individuals who do not pose a threat. Entrapment wastes government resources and undermines public confidence in the justice system and law enforcement. Although the FBI's problematic surveillance of Muslim and Middle Eastern communities stems from the use of all types of informants and not merely those recruited with immigration promises, a modification to the use of immigration law in rewarding or coercing terrorism informants would provide a step toward producing more useful intelligence and reducing the risk of harm to innocent individuals.

\section{A. Mosque Surveillance Chills Free Speech}

In 2002, Attorney General John Ashcroft updated the Attorney General's FBI Guidelines, ${ }^{68}$ and did away with restrictions on entering mosques and other places of worship. ${ }^{69}$ The Guidelines read in pertinent part: "For the purpose of

67. Harris, supra note 23, at 129-31.

68. OFFICE OF THE ATtORNEY GEN., THE ATtORNEY GENERAL'S GUIDELINES ON GENERAL CRIMES, RACKETEERING ENTERPRISE AND TERRORISM ENTERPRISE INVESTIGATIONS (2002) [hereinafter ATTORNEY GEN. GUIDELINES].

69. Attorney General John Ashcroft, Remarks on the Attorney General Guidelines 3 (May 30, 2002) ("Today, I am clarifying that, for the specific purpose of detecting or preventing terrorist activities, FBI field agents may enter public places and attend events open to other citizens, unless they are barred from attending by the Constitution or federal law."); see also DAVID COLE \& JAMES X. DEMPSEY, TERRORISM AND THE CONSTITUTION 94 (2006) ("Prior to the Ashcroft changes, the FBI was not prohibited from going to mosques, political rallies, and other 'public' places to observe and 
detecting or preventing terrorist activities, the FBI is authorized to visit any place and attend any event that is open to the public, on the same terms and conditions as members of the public generally." ${ }^{70}$ Thus, FBI agents can now enter any mosque or attend any religious gathering without probable cause. Under the previous Guidelines, issued in 1979 by Attorney General Benjamin Civiletti, an agent could only conduct an investigation where "the facts or circumstances reasonably indicate that two or more persons are engaged in an enterprise for the purpose of furthering the political or social goals . . . through activities that involve force or violence and a violation of the criminal laws of the United States."71

In the past, the FBI's Domestic Investigations and Operations Guide ("DIOG”), which provides guidance on implementing the Attorney General's Guidelines, allowed supervisory agents to delegate to inferior agents decisions concerning the surveillance of mosques and other religious gathering places. ${ }^{72}$ Recently, however, restrictions have been slightly strengthened by requiring agents in charge of the field operations to approve surveillance. ${ }^{73}$ Nevertheless, this change may not really improve matters, as numerous instances of mosque surveillance have already eroded Muslim communities' trust of law enforcement. ${ }^{74}$ By placing informants in places of worship and cultural spaces, the FBI has chilled free speech and damaged the most reliable way of obtaining accurate terrorism intelligence from these communities.

In a well-publicized and egregious case, an FBI informant named Craig Monteilh was assigned to surveil a mosque in Irvine, California. ${ }^{75}$ The FBI instructed Monteilh, a convicted felon working as a paid informant, ${ }^{76}$ to

record what was said but, in the past, in domestic terrorism investigations, it had to be guided by the criminal nexus .... [I]t had to have some reason to believe that terrorism might be discussed.”).

70. AtTORNEY GEN. GUIDELINES, supra note 68, at 22 (emphasis added).

71. OFFICE OF THE ATtORNEy GEN., THE ATtORNEY GENERAL’S GUIDELINES ON GENERAL CRIMES, RACKETEERING ENTERPRISE, AND DOMESTIC SECURITY/TERRORISM INVESTIGATIONS (1989), available at http://www.fas.org/irp/agency/doj/fbi/generalcrimea.htm\#domestic. The Guidelines were subject to a minor update in 1989 by Attorney General Dick Thornburgh.

72. FED. BUREAU OF INVESTIGATION, DOMESTIC INVESTIGATIONS AND OPERATIONS GUIDE (DIOG) 31 (2009), available at http://vault.fbi.gov/FBI\%20Domestic\%20Investigations\%20and\%20 Operations\%20Guide\%20\%28DIOG\%29/diog-section-4-2008-version-training-material-and-relateddocuments/fbi-domestic-investigations-and-operations-guide-diog-2008-version-training-material-andrelated-documents-part-01-of-05/view; Charlie Savage, F.B.I. Agents Get Leeway To Push Privacy Bounds, NY TIMES, June 13, 2011, at A1.

73. See Savage, supra note 72.

74. See, e.g., Markon, supra note 23; Charlene Muhammad, FBI Infiltrates Southern California Mosques, FINAL CALL (Apr. 14, 2009, 4:36 PM) http://www.finalcall.com/artman/publish/ article_5918.shtml; Dina Temple-Raston, Imam Arrests Show Shift in Muslim Outreach Effort, NPR (July 19, 2011, 12:01 AM), http://www.npr.org/2011/07/19/137767710/imam-arrests-show-shift-inmuslim-outreach-effort.

75. Markon, supra note 23.

76. Muhammad, supra note 74; Nick Shou, The FBI, the Islamic Center of Irvine and Craig Monteilh: Who Was Conning Whom?, OC WEEKLY (Apr. 30, 2009), http://www.ocweekly.com/200904-30/news/craig-monteilh/. 
indiscriminately surveil worshippers at the mosque, without concentrating on a particular target or activity. ${ }^{77}$ After congregants noticed Monteilh's inflammatory rhetoric and repeated talks about instigating terrorism, they reported him to the FBI. ${ }^{78}$ The FBI failed to investigate further, and after the arrest of another suspected terrorist, Monteilh revealed his identity as an FBI informant. $^{79}$ This incensed the Islamic community, in part because an FBI Assistant Director had promised a year earlier that the agency would not surveil mosques. ${ }^{80}$ In response, Islamic groups like the Council on American-Islamic Relations and the American Muslim Task Force on Civil Rights and Elections, which had previously cooperated with the FBI and urged community members to do the same, reversed course and stopped their outreach efforts to aid law enforcement. $^{81}$ In the end, Craig Monteilh's story is just one of many that demonstrate why Muslim communities have soured on helping the FBI locate suspicious people within their communities. ${ }^{82}$

Although Monteilh was neither an immigrant nor was offered immigration incentives in return for intelligence, his story shows how the use of informants can potentially damage both law enforcement and immigrant communities. Monteilh's story also illustrates why many communities feel mosque surveillance infringes on their freedom of speech. Once a community becomes aware that FBI informants may be surveilling its mosques, the fear that informants will target them chills the free exchange and expression of ideas and speech. ${ }^{83}$ Given the constitutional guarantees of the First Amendment, places of worship should be treated with utmost sensitivity by law enforcement, ${ }^{84}$ as the self-editing that occurs when people know they are being watched curtails the free exchange of ideas.

The very knowledge of potential surveillance may caution people against discussing their political and religious viewpoints for fear of being targeted by informants like Monteilh. Consequently, mosque attendance falls ${ }^{85}$ and community cohesion suffers, thwarting the First Amendment's protection of free expression. Even those not harboring extreme viewpoints may be

77. Shou, supra note 76 .

78. Id.

79. Id.

80. Id.

81. Id.

82. Harris, supra note 23, at 23-26; Samantha Henry, NJ FBI: NYPD Monitoring Damaged Public Trust, AssocIATED PRESS (Mar. 7, 2012), http://www.ap.org/Content/AP-In-The-News/2012 /NJ-FBI-NYPD-monitoring-damaged-public-trust; Omar Sacirbey, Muslims and ACLU Sue FBI Over Mosque Surveillance, HuFFINGTON POST (Feb. 23, 2011, 9:49 PM), http://www.huffingtonpost.com /2011/02/23/muslims-and-aclu-sue-fbi-_n_827339.html.

83. U.S. CONST. amend. I; Harris, supra note 23, at 165-66.

84. Harris, supra note 23, at 166.

85. See Brief of Amicus Curiae the Council on American-Islamic Relations in Support of the Respondent at 4, 16-19, United States v. Jones, 132 S. Ct. 945 (2012) (No. 10-1259); Dina TempleRaston, Mosque Attendance Falls After Terrorism Arrests, NPR (May 30, 2007, 7:14 PM), http://www.npr.org/templates/story/story.php?storyId=10529148. 
dissuaded from political speech for fear of misinterpretation. For example, after revelations of potential FBI surveillance surfaced at the Islamic Center of Irvine, congregant Omar Turbi attested, "It gives you a little bit of apprehension about who you trust .... Makes you think twice about what you say; what if people misunderstand you?" 86 Similarly, the executive director of the Council on American-Islamic Relations in Anaheim stated, "Some average Muslims interested only in praying are avoiding mosques for fear of somehow being monitored or profiled .... Everybody is afraid, and it is leading to an infringement of the free practice of our religion." ${ }^{\text {, } 7}$ Although some states like Indiana, Pennsylvania, and Oregon have enacted laws prohibiting the surveillance of religious sites without reasonable suspicion, ${ }^{88}$ it should not be necessary to rely on state laws to protect the integrity and values of the First Amendment.

\section{B. Mosque Surveillance Encourages Religious and Ethnic Profiling}

In addition to eroding the First Amendment's free speech rights of Muslims and Middle Easterners, the FBI's informant surveillance tactics also inappropriately target these religious and ethnic groups. Most of the organizations designated as Foreign Terrorist Organizations by the State Department are Muslim or Arab groups. ${ }^{89}$ Many post-9/11 policies, like the extensive detention of Muslims and Middle Easterners, indicate that the federal government views Muslims and Middle Eastern immigrants as potential terrorists. ${ }^{90}$ Popular perception of Muslims has moved in the same direction, with huge opposition, for example, to the construction of an Islamic community center-Park 51-near the site of the World Trade Center in New York. ${ }^{91}$ Other examples include state laws banning the use of Shari'ah law in judicial decisions $^{92}$ and Islamophobia ${ }^{93}$ rising in the United States ${ }^{94}$ and abroad. ${ }^{95}$

86. Teresa Watanabe \& Paloma Equivel, Muslims Say FBI Spying Is Causing Anxiety; Use of an Informant in Orange County Leads Some To Shun Mosques, LA TIMES, Mar. 1, 2009, at B1.

87. Id.

88. IND. CoDE § 5-2-4-5 (2012); OR. REv. StAT. § 181.575 (2011); 18 PA. Cons. StAT. ANN. $\S 9106(b)(2)$ (West 2012).

89. See Chapter 6. Foreign Terrorist Organizations, U.S. DeP’T OF STATE (May 30, 2013), http://www.state.gov/j/ct/rls/crt/2012/209989.htm; U.S. DEP'T OF STATE, supra note 17.

90. Said, supra note 21, at 705; see also Leti Volpp, The Citizen and the Terrorist, 49 UCLA L. REV. 1575, 1577-78 (2002).

91. Ishaan Tharoor, Mosque Protests Add Note of Discord to 9/11 Remembrances, TimE (Sept. 11, 2010), http://www.time.com/time/nation/article/0,8599,2017674,00.html.

92. Michel Martin, States Move To Ban Islamic Sharia Law, NPR (Mar. 11, 2011, 12:00 PM), http://www.npr.org/2011/03/11/134458058/States-Move-To-Ban-Islamic-Sharia-Law.

93. Islamophobia literally means "anxiety of Islam.” It is used here to identify a cultural and social fear of Islam that was first experienced by Judeo-Christian cultures and recently perpetuated by popular notions of Islam in the United States. Dr. Hatem Bazian, Senior Lecturer at the University of California, Berkeley's Department of Near Eastern Studies and Professor of Islamic Law and Arabic at Zaytuna College of California, states that Islamophobia is "aggregating members of the AMEMSA community into a threatening, homogeneous and undifferentiated community. Islamophobia are 
By sending immigrant informants into mosques and religious and ethnic communities with little more than a vague directive to find terrorists, the FBI perpetuates ethnic profiling and the conflation of Islam and terrorism. In recruiting terrorism informants from the immigrant population, the FBI puts an ethnic and religious face on terrorism, and perpetuates the popular perception of what terrorists look like. Sending these informants into mosques and immigrant communities greatly increases the chances that alleged suspects fit the ethnic and religious stereotypes of terrorists. Put differently, if an informant is assigned to surveil a mosque, the chances of the informant bringing back a non-Muslim or non-Middle Eastern suspect are low.

This surveillance policy becomes a vicious cycle. The FBI recruits immigrant individuals from suspect communities to become informants, pressures them into producing terrorism suspects that fit the popular perception of what terrorists are like, and then prosecutes these suspected terrorists. All this reinforces the public conflation of immigrants, Muslims, Middle Easterners, and terrorists. Ethnic and religious profiling further alienates Muslim and Middle Eastern communities, and deepens their mistrust for government. $^{96}$ Additionally, by predisposing many Americans to view Muslims, immigrants, and Middle Easterners as potential terrorist threats, ethnic and religious profiling may also bias juries in terrorism prosecutions. ${ }^{97}$ Although suspects often claim entrapment as a defense, after 9/11 the entrapment defense has never been successfully used in terrorism cases. ${ }^{98}$ In fact, many, if not most, terrorism cases never reach the jury because the chances of successfully defending against terrorism charges after 9/11 are almost nonexistent. ${ }^{99}$ Popular stereotypes concerning Muslims and Middle Easterners play a role in this. Although the use of immigration law in recruiting informants is only one of many factors contributing to this harmful cycle, the use of coercive tactics like immigration law to recruit informants creates a

words, deeds and actions that malign the entire faith.” SF HUMAN RIGHTS COMMISSION, supra note 9, at 10. For more, see PETER GOTTSCHALK \& GABRIEL GREENBERG, ISLAMOPHOBIA: MAKING MUSLIMS THE ENEMY (2008).

94. Debra L. Oswald, Understanding Anti-Arab Reactions Post-9/11: The Role of Threats, Social Categories, and Personal Ideologies, 35 J. APPLIED SOC. PSYCHOL. 1775 (2005).

95. Christopher AlLEN \& JøRGEN S. NiELSEN, EUROPEAN MONITORING CTR. ON RACISM AND XENOPHOBIA, SUMMARY REPORT ON ISLAMOPHOBIA IN THE EU AFTER 11 SEPTEMBER 2001, at 5 (2002), available at http://fra.europa.eu/sites/default/files/fra_uploads/199-Synthesis-report_en.pdf.

96. Harris, supra note 23, at 23-26.

97. Said, supra note 20, at 733-35.

98. Dina Temple-Raston, Confidential Informers Play Complex Role for FBI, NPR (Nov. 22, 2011, 1:00 PM), http:/www.npr.org/2011/11/22/142661876/confidential-informers-play-complex -role-for-fbi.

99. Said, supra note 21; The Informants, supra note 8, at 41-42 ("Nearly two-thirds of all terrorism prosecutions since 9/11 have ended in guilty pleas, and experts hypothesize that it's difficult for such defendants to get a fair trial. 'The plots people are accused of being part of — attacking subway systems or trying to bomb a building — are so frightening that they can overwhelm a jury,' notes David Cole, a Georgetown University law professor who has studied these types of cases.”). 
higher risk of unfounded terrorism prosecutions against innocent individuals who do not pose a risk. Consequently, this fuels the public perception that a stereotypical terrorist is a Middle Easterner or Muslim.

\section{Terrorism Informants' Presence in Muslim and Middle Eastern Communities Damages Intelligence Efforts}

Many argue that tactics like recruiting informants through immigration law and surveilling mosques are necessary to prevent terrorist attacks, and that national security must be the nation's top priority, whatever the cost. These arguments fail to recognize that when informants lack a specific target and direction, the gathered intelligence does not necessarily enhance the nation's security. Instead, the FBI - with little concern for the actual gravity of the original threat posed by the suspect-creates an elaborate terrorism plot for the surveillance targets to participate in. ${ }^{100}$ After 9/11, many individuals who showed no signs of violence or extremism prior to involvement with informants and government-created plots have been prosecuted under terrorism charges. ${ }^{101}$ Until the informants provided the means, these individuals did not have the finances or the proper connections to conceive and carry out these terrorism plans. Although orchestrating these plots makes the FBI's preventative stance appear successful in the public eye, it diverts law enforcement resources from focusing on real targets.

Moreover, Professor David A. Harris claims that "the unregulated use of informants in mosques and other religious and cultural settings can also do great damage because it poses the risk of cutting off our best possible source of intelligence: the voluntary, cooperative relationships that have developed between law enforcement and Muslim communities." ${ }^{02}$ Having community members report suspicious information to the FBI may be a more effective way of obtaining reliable terrorism intelligence from these communities. ${ }^{103}$ For example, in the few domestic terrorist prosecutions where a terrorist attack plan actually existed prior to informant involvement, community members who had noticed something amiss were the first to alert the FBI and identify the subjects. ${ }^{104}$ In fact, since 9/11, community members have assisted law enforcement in stopping potential terrorism plots in a number of cases. ${ }^{105} \mathrm{~A}$

100. See, e.g., United States v. Cromitie, 781 F. Supp. 2d 211 (S.D.N.Y. 2011) (discussing the threat posed by defendant Cromitie).

101. See The Informants, supra note 8, at 38-39.

102. Harris, supra note 23, at 131.

103. See id. at 132-34; see also Alejandro J. Beutel, Muslim Pub. AfFairs Council, Policy Report: Data on Post-9/11 TerRorism IN tHe United States 10-11 (2011) (listing instances in which community involvement has successfully thwarted terrorist attacks).

104. See BEUTEL, supra note 103, at 10-11; Matthew Purdy \& Lowell Bergman, Unclear Danger: Inside the Lackawanna Terror Case, NY TIMES, Oct. 12, 2003, at A1.

105. For example, the "Lackawanna Six" case was first brought to FBI attention by an anonymous tipster from the Yemeni community in Lackawanna. See Inside the Sleeper Cell Chronology: The Lackawanna Investigation, PBS FRONTLINE, http://www.pbs.org/wgbh/pages/ 
recent example, the case of Umar Farouk Abdulmutallab, the "Underwear Bomber," shows that the attempted bombing could have been prevented had law enforcement heeded the warnings that Abdulmutallab's father gave the CIA at the U.S. embassy in Nigeria. ${ }^{106}$ As the president of the San Francisco Board of Supervisors and former criminal prosecutor, David Chiu testified regarding the Arab, Middle Eastern, Muslim, and South Asian communities in San Francisco: "[W]ithout that level of cooperation, that level of trust, everything falls apart.... [S] Jurveillance only serves to continue to drive wedges when cooperation is what is needed most." ${ }^{107}$

Analogous to the way informants in mosques target vulnerable individuals despite these individuals' lack of connection to terrorist organizations or predilection for extremism, a 2011 study by the Migration Policy Institute demonstrates a similar phenomenon within other communities. ${ }^{108}$ The $287(\mathrm{~g})$ initiative, named after the section of the Immigration and Nationality Act that authorized it, allows ICE to enter into memorandums of agreement with state and local law enforcement agencies, empowering these agencies to directly enforce immigration laws. ${ }^{109}$ However, the study found that half of the jurisdictions using 287(g) did not direct their enforcement efforts toward serious or violent offenders, ${ }^{110}$ as the $287(\mathrm{~g})$ initiative had originally envisioned. ${ }^{111}$ Instead, these jurisdictions sought to deport as many offenders as possible regardless of the severity of the crime. ${ }^{112}$

Study respondents "believe that 287(g) program activities affect the community in distinct and adverse ways, including by causing declines in Latino immigrant populations, [creating] avoid[ance of] public places by these populations, chang[ing] [] driving behavior, [creating] fear and mistrust of the police and other authorities, and reduc[ing] crime reporting." ${ }^{113}$ These behaviors were more acute in jurisdictions with nontargeted enforcement,

frontline/shows/sleeper/inside/cron.html (last visited Oct. 18, 2013). Similarly, in the "Paintball Eleven" case, local community members alerted law enforcement of the group's suspicious activity. See Mary Beth Sheridan, Hardball Tactics in an Era of Threats, WASH. Post, Sept. 3, 2006, at A1. For more examples, see BEUTEL, supra note 103, at 10-11.

106. Abdulmutallab Shocks Family, Friends, CBSNEWs.COM (Dec. 29, 2009, 5:49 PM) http://www.cbsnews.com/stories/2009/12/28/world/main6029782.shtml.

107. SF HUMAN RIGHTS COMMISSION, supra note 9, at 31.

108. Randy Capps et al., Migration Pol'y Inst., Delegation and Divergence: A STUDY OF THE 287(G) STATE AND LOCAL IMMIGRATION ENFORCEMENT (2011).

109. 8 U.S.C. § 1357(g) (2012) (“[T]he Attorney General may enter into a written agreement with a State, or any political subdivision of a State, pursuant to which an officer or employee of the State or subdivision, who is determined by the Attorney General to be qualified to perform a function of an immigration officer in relation to the investigation, apprehension, or detention of aliens in the United States (including the transportation of such aliens across State lines to detention centers), may carry out such function at the expense of the State or political subdivision and to the extent consistent with State and local law.”).

110. CAPPS ET AL., supra note 108, at 18-19.

111. Id. at 11-12.

112. See id. at 7.

113. Id. at 38 . 
where any offense could constitute grounds for deportation. ${ }^{114}$ Just as Latino immigrant communities became distrustful of law enforcement and withdrew from crime reporting when threatened with deportation, so did Muslim and Middle Eastern communities when threatened with FBI surveillance of communal spaces. As the study notes, "these operations can generate widespread distrust of police. Such distrust in turn prompts immigrants to change their behavior to avoid contact with police and other authorities.",115

In order to procure accurate intelligence from any community, a relationship of trust and respect between law enforcement and the community must exist. ${ }^{116}$ However, from the mass arrest and detention of Muslims shortly after $9 / 11^{117}$ to the ongoing allegations of ethnic and religious profiling today, ${ }^{118}$ the federal government has made serious errors in dealing with Muslim and Middle Eastern communities since 9/11. While the government recognizes that community policing ${ }^{119}$ is the best way to obtain reliable intelligence, ${ }^{120}$ the FBI is caught between two contradictory strategies and must choose between sending informants into mosques without reasonable suspicion, and gaining the trust and cooperation of Muslim and Middle Eastern communities. As one congregant in a surveilled mosque observed, "The FBI wants to treat the Muslim community as a partner while investigating us behind our backs ... . They can't have it both ways." ${ }^{121}$ While it is unrealistic to think that the FBI will stop using informants in these communities, a more restrained use of informants based on reasonable suspicion of wrongdoing would mitigate perceived damages to community relations. Requiring the FBI to have preexisting reasonable suspicion would add credibility to the agency and alleviate some of the fear surrounding terrorism investigations involving informants.

114. Id. at 43 ("In addition to short-term outmigration, we also found evidence of fear, distrust of police, and immigrants avoiding public spaces in the study sites of Cobb, Gwinnett, Frederick, and Prince William counties, and to a lesser extent in Colorado. These impacts have arisen because of the combination of widespread traffic enforcement in immigrant neighborhoods and the subsequent processing of traffic violators through the $287(\mathrm{~g})$ program - a combination that means minor traffic violations can result in removal.”).

115. Id.

116. Harris, supra note 23, at 134.

117. Id. at 135 .

118. See Brief of Amicus Curiae, supra note 85, at 13 ("Covert surveillance of American Muslims, driven by religious profiling, has led to a litany of social harms suffered disproportionately both by individuals within the community and the community as a whole.”).

119. Community policing is a "law enforcement strategy emphasizing, '... collaborative partnerships between the law enforcement agency and the individuals and organizations they serve to develop solutions to problems and increase trust in police.’” BEUTEL, supra note 103, at 10.

120. Harris, supra note 23, at 137-38 (noting how the former Secretary of Homeland Security, community policing experts Robert Trojanosicz and Bonnie Buqueroux, the Deputy Director of the FBI's National Security Branch Philip Mudd, and others have all indicated that community cooperation is the most desirable and dependable source of information).

121. Markon, supra note 61 (quoting congregant Omar Kurdi). 
By virtue of their connections and daily interactions, those active in a particular community are in the best position to notice when others in the community act strangely. Unlike informants who may be new to the community and who other members may view with suspicion, well-established community members may already know what is going on in their community and can more accurately spot genuine threats.

Notably, the argument that Muslims and Middle Easterners are in the best position to provide accurate intelligence on terrorist activities within their respective communities risks fueling the government's conflation of those communities with terrorism. ${ }^{122}$ However, in analyzing how best to procure counterterrorism intelligence, it would be amiss not to recognize the FBI's and other law enforcement agencies' heavy focus on Muslim and Middle Eastern communities. This is largely due to most recognized foreign terrorist organizations being based out of the Middle East or having Islamic ties. ${ }^{123}$ Law enforcement efforts, immigration law, surveillance policies, and pre-9/11 incidents like the 1993 attack on the World Trade Center have categorized the typical terrorist as male, Middle Eastern, and devoutly Muslim. ${ }^{124}$ The reality is that even though recently immigrated Muslims and Middle Easterners have become synonymous with terrorism, terrorists come from various ethnicities, religions, and communities. ${ }^{125}$

While acknowledging and attempting not to replicate that stereotype, this Comment seeks to recommend ways to improve the relationship between law enforcement and potential terrorism informants who typically belong to the same religion or ethnicity as those they surveil. The government's focus on Muslim and Middle Eastern communities as potential breeding grounds for terrorist groups also directs the focus of this Comment. However, this Comment resists the broad characterization of these communities as prone to extremism and violence. In fact, a recent statistical analysis of terrorism activity after 9/11 discredits the stereotype that Muslims and Middle Easterners account for most of the terrorism within the United States. ${ }^{126}$ In total, the report found that U.S.-originated non-Muslims accounted for 107 post-9/11 plots while U.S.-originated Muslims accounted for $49 .{ }^{127}$ Conversely, the report found that cooperation with Muslim communities helped prevent 40 percent of all Al-Qaeda plots after 9/11. ${ }^{128}$ As the report notes, "[a] singular focus on Muslim terrorists is both bad for national security and civil society ... . [N]umerous studies and experts have stated that there is no reliable

122. For a more complete discussion of how Muslim and Middle Easterners are framed as presumptive terrorist suspects, see Said, supra note 21, at 704-07.

123. See supra note 17.

124. Said, supra note 20, at 704-06.

125. Id.

126. BEUTEL, supra note 103, at 5-6.

127. Id. at 6.

128. Id. at 3 . 
'terrorist profile.", ${ }^{129}$ When compared to the actual threat posed by members of Muslim and Middle Eastern communities, then, the FBI's explicit target of Muslim and Middle Eastern communities is excessive.

\section{Indiscriminate Use of Informants Leads to Entrapment}

Entrapment is another problem arising from the broad use of terrorism informants. Since 9/11, many informants have been involved with cases where the government effectively created a terrorist plot and then pressured the defendant into agreeing to it. ${ }^{130}$ As the Council on American-Islamic Relations stated in a 2009 report, informants "are paid and/or rewarded based on the amount of information they produce; therefore, these informants are inclined to exaggerate, instigate, and fabricate cases of a 'terrorist' nature." ${ }^{131}$ Many of the terrorist plots the FBI touts to the public as victories have been the result of informants pressuring vulnerable, young, or impressionable individuals who lacked ties to terrorist organizations or prior terrorist inclinations. ${ }^{132}$

In United States v. Cromitie, ${ }^{133}$ a striking case that illustrates the extent to which informants and their handlers can go in fabricating prosecutions, the defendant pled outrageous government conduct as a defense. ${ }^{134}$ In contrast to an entrapment defense, claims of outrageous government conduct focus on government action rather than the defendant's. ${ }^{135}$

Shahed Hussain, the informant in Cromitie, began working for the FBI in 2002 after facing deportation and criminal charges over a Department of Motor Vehicle scam he ran. For his work as an informant, Hussain was paid around $\$ 100,000{ }^{136}$ Following Cromitie’s conviction for conspiring to commit terrorist acts, Cromitie moved to dismiss the indictment based on the outrageous conduct of the government and, specifically, Hussain. ${ }^{137}$ Before his arrest, Cromitie expressed to Hussain interest in joining a Pakistani terrorist group. In subsequent conversations with Hussain, however, Cromitie reacted

129. Id. at 9 .

130. Said, supra note 20, at 715-18, 20 (detailing several of these cases).

131. COUNCIL ON AMERICAN-ISLAMIC RELATIONS GREATER LOS ANGELES AREA CHAPTER, THE FBI's USE OF INFORMANTS, RECRUITMENT AND INTIMIDATION WITHIN MUSLIM COMMUNITIES 1 (2009).

132. Said, supra note 21, at 715-32.

133. United States v. Cromitie, 781 F. Supp. 2d 211 (S.D.N.Y. 2011).

134. Id. at 213-14. Although the outrageous government conduct defense is similar to the objective test for entrapment, they are distinct defenses. An outrageous government conduct claim could succeed in the same case as a failed entrapment defense, because the former looks at only the government's behavior, whereas the latter looks only at the predisposition of the defendant. 21 AM. JuR. 2D Criminal Law § 425 (2013).

135. Hampton v. United States, 425 U.S. 484, 488-89 (1976).

136. The Informants, supra note 8, at 34-35. Subsequently, Shaheed Hussain was implicated in an alleged attempt to entrap Khalifah al-Akili, a Pittsburgh man. Hamed Aleaziz, Wondering If Your "Jihadist" Friend Is With the FBI?, MOTHER JONES (Mar. 20, 2012, 3:30 AM), http://www.mother jones.com/mojo/2012/03/shahed-hussain-khalifah-al-akili.

137. 781 F. Supp. 2d at 213. 
negatively to suggestions of suicide bombing. ${ }^{138}$ Further, in recorded conversations between Cromitie and Hussain, Cromitie at times sounded ambivalent about jihad and other times expressed violent sentiments. ${ }^{139}$ However, "whenever Hussain asked Cromitie to act on those sentiments ... Cromitie did none of the above." ${ }^{140}$ Hussain then escalated the pressure, promising Cromitie a BMW for carrying out a mission and offering him money for "doing jihad." 141

In addition to the pressure exerted on Cromitie to commit a crime, the FBI made other serious missteps while building its case against him. During the investigation, the FBI failed to corroborate Cromitie's alleged past crimes and ties to Afghanistan. ${ }^{142}$ The court specifically noted:

[B]efore deciding that the defendants (particularly Cromitie, who was in their sights for nine months) presented any real danger, the Government appears to have done minimal due diligence, relying instead on reports from its Confidential Informant ... no one thought it necessary to check before offering a jihadist opportunity to a man who had no contact with any extremist groups and no history of anything other than drug crimes. ${ }^{143}$

In fact, although FBI officials concluded during a meeting that Cromitie "was unlikely to commit an act without the support of the FBI source," officials nevertheless continued the investigation. ${ }^{144}$

Even after Hussain realized that Cromitie's stories of visiting Afghanistan and committing crimes were false, he continued to offer Cromitie money in exchange for committing crimes, promising him up to $\$ 250,000$ without authorization from the FBI. ${ }^{145}$ After Cromitie lost his job at Wal-Mart and grew desperate for money, Hussain "leveraged that unfortunate situation to coax Cromitie to go forward with a jihadist plot. Cromitie protested that he did not want to be a martyr, but nonetheless agreed to go forward." ${ }^{146}$ Cromitie helped recruit several lookouts, surveilled potential sites, and planted what he thought was a bomb. Cromitie was subsequently arrested. ${ }^{147}$ The court described the government's involvement in this plot:

As it turns out, the Government did absolutely everything that the defense predicted in its previous motion to dismiss the indictment. The Government indisputably "manufactured" the crimes of which

138. Id. at 216-17.

139. Id. at 216-18.

140. Id. at 218.

141. Id.

142. Id. at 221.

143. Id.

144. Id. at 226.

145. Id. at 219.

146. Id. at 220 .

147. Id. 
defendants stand convicted. The Government invented all of the details of the scheme-many of them, such as the trip to Connecticut and the inclusion of Stewart AFB as a target, for specific legal purposes of which the defendants could not possibly have been aware.... The Government selected the targets. The Government designed and built the phony ordnance that the defendants planted .... . The Government provided every item used in the plot .... The Government funded the entire project. And the Government, through its agent, offered the defendants large sums of money, contingent on the participation in the heinous scheme. ${ }^{148}$

Surprisingly, the court nevertheless concluded that the government's actions were neither outrageous nor shocking. ${ }^{149}$ In fact, the court stated that it would have been negligent for the FBI not to investigate Cromitie after the statements he made regarding Jews, the United States, and Pakistan-despite these statements never becoming specific threats or incitements to action. ${ }^{150}$ Even though the court did not find outrageous conduct, it nevertheless recognized that

[Hussain, as the informant,] was the prime mover and instigator of all the criminal activity that occurred, right up until the last moments of the conspiracy, when he had to stop the car he was driving and "arm" the "explosive device" because the utterly inept Cromitie could not figure out how to do it. ${ }^{151}$

Although "[t]his court is not familiar with a case in which so many different tactics were used on a single individual... Cromitie justified the Government's persistence when he proved to be ready and willing to commit terrorist acts." 152

Cromitie raises the question whether government action would ever rise to the level of outrageousness that the courts demand. In Cromitie, the court suggested that only duress, physical deprivation, or coercion by the government is prohibited when pursuing a potential prosecution. ${ }^{153}$ Although Cromitie's sentiments toward Americans and Jews are neither admirable nor politically correct, the court strongly suggested that he never posed a real threat. ${ }^{154}$

148. Id. at 220-21.

149. Id. at 221.

150. Id. at 222. However, the first several meetings with the informant in this case were not taped. Id. Thus, how the FBI would verify that Cromitie was worthy of investigation is questionable. Furthermore, all of Cromitie's statements to Hussain before Hussain asked him to join the government-created terrorist plot did not reference specific actions, and thus should have been protected by the First Amendment as political statements. Id.

151. Id. at 226 .

152. Id. at 223.

153. Id. ("Hussain may have spent a half a year or more trying to persuade Cromitie to go forward with a jihadist mission, but there was no coercion of any sort, no suggestion of duress and no physical deprivation. After Chin, I harbor considerable doubt whether anything less would ever qualify as 'outrageous' misconduct in this Circuit.”).

154. Id. at 226. The court suggested that Cromitie never posed a threat, stating: 
Nevertheless, despite its aggressive actions, the government received nothing more than a verbal slap on the wrist. ${ }^{155}$ Stories like Cromitie's underscore Muslim and Middle Eastern communities' fears of informants. Community members realize that the chances of a successful defense against the government based on the tactics of an informant and the FBI are extremely low, regardless of the coerciveness of the methods used.

III.

\section{LIMITATIONS ON THE FBI'S USE OF INFORMANTS}

Cromitie demonstrates that the FBI lacks substantial restraints on how it recruits and uses informants. Currently, there are four restrictions on how the FBI recruits informants: (1) internal FBI limitations, (2) constitutional limitations, (3) the entrapment defense and the outrageous government conduct doctrine, and (4) enforcement of nondeportation agreements in plea bargains. Because these limitations have neither curtailed the FBI's mismanagement of informants nor ensured a high degree of accuracy in information obtained, these restrictions have failed to protect both the public from terrorism and informants from abuse. ${ }^{156}$

\section{A. Attorney General Guidelines}

The Attorney General's Guidelines on FBI Confidential Human Sources $^{157}$ ("Guidelines"), issued in 2006 by the Department of Justice, ${ }^{158}$ are

[A]fter reviewing the record yet again, I am left with the firm conviction that if the Government had simply kept an eye on Cromitie, and moved on to other investigations, nothing like the events of May 9, 2009 would ever have occurred .... I am constrained to agree with the FBI's assessment ... that "Cromitie was unlikely to commit an act without the support of the FBI source ...."

Id. (citation omitted).

155. The court stated:

There were undoubtedly other ways to conduct an investigation into James Cromitie. This court has long been concerned that the Government failed to make a few fairly elementary inquiries at the outset-inquiries that would have revealed Cromitie to be a liar and a blowhard long before the Government began to suspect as much. Furthermore, it is troubling, for many months, the Government dangled what had to be almost irresistible temptation in front of an impoverished man from what I have come (after literally dozens of cases) to view as the saddest and most dysfunctional community in the Southern District of New York.

Id.

156. See Delores Jones-Brown \& Jon M. Shane, AClu of New Jersey, AN EXPLORATORY STUDY OF THE USE OF CONFIDENTIAL INFORMANTS IN NEW JERSEY 10-11, 35, 52-55 (2011), available at http://media.nj.com/ledgerupdates_impact/other/report.pdf (noting the use of unreliable informants, the coercive police practices to induce informant cooperation, and the police's failure to protect informants in New Jersey); INSPECTOR GEN. COMPLIANCE STUDY, supra note 45, at 7-9; Mary Nicol Bowman, Truth or Consequences: Self-Incriminating Statements and Informant Veracity, 40 N.M. L. REV. 225, 229 (2010).

157. U.S. DEP'T OF JUSTICE, THE ATTORNEY GENERAL's GUIDELINES REGARDING THE USE OF FBI CONFIDENTIAL HUMAN SOURCES (2006), available at www.justice.gov/oip/docs/agguidelines-use-of-fbi-chs.pdf [hereinafter ATTORNEY GEN. CONFIDENTIAL SOURCES GUIDELINES].

158. NATAPOFF, supra note 21, at 141. 
agency guidelines, not regulations, and as such have no binding legal effect. ${ }^{159}$ Much of the problem of FBI informant misuse stems from this fact. The Guidelines outline the rules the FBI should follow in undercover investigations involving informants, which include documenting new informants and recording agreements made. ${ }^{160}$ The Guidelines are also subject to review and modification by the Attorney General in accordance with federal laws, and are afforded great deference by the courts. ${ }^{161}$ The major problems with the Guidelines, however, are that they lack consequences, are not subject to judicial review, and are not followed by agents. ${ }^{162}$

While the Guidelines may have internal consequences ${ }^{163}$ for FBI agents who violate them, they have no meaningful effect beyond internal regulation and cannot be enforced by the public via judicial review. ${ }^{164}$ Judicial review for violations only occurs when criminal prosecutions reveal the FBI's activities in the investigation. ${ }^{165}$ However, the informants in these cases typically remain confidential, and any inquiry into their actions does not extend beyond the handling agent's conduct and the recruitment methods used. ${ }^{166}$

Evidence shows that in many cases, FBI agents fail to follow the Guidelines when recruiting and handling informants. A 2005 study conducted by the Department of Justice Office of the Inspector General found that the FBI did not provide enough support to agents to properly follow the pre-2006 Attorney General Guidelines Regarding the Use of Confidential Informants. ${ }^{167}$ In fact, noncompliance with the guidelines was a problem in 87 percent of the cases the Inspector General reviewed. In particular, agents failed to properly review the suitability of potential informants, properly document informants' illegal activities, and notify informants of their limitations. ${ }^{168}$ Given the high levels of noncompliance and agents' nearly unlimited discretion in extending immigration rewards, agent abuse is likely also high.

159. Schreiber, supra note 39, at 340.

160. Id.

161. Dru Stevenson, Entrapment and Terrorism, 49 B.C. L. REV. 125, 162-63 (2008).

162. INSPECTOR GEN. COMPLIANCE STUDY, supra note 45, at 7-9 (stating that a survey involving 120 confidential informant files found compliance errors in 87 percent of the files).

163. Stevenson, supra note 161, at 163 ("The guidelines themselves provide no sanctions for violations of its requirements, other than discretionary removal of individual agents from an operation by the agent's superiors in the FBI or the Department of Justice.”).

164. Fed. Bureau of INVESTIGATION, 2 FreEdOM OF INFORMATION AND PRIVACy ACTS MANUAL OF INVESTIGATIVE OPERATIONS AND GUIDELINES 137-73 (1998), available at http://archive.org/stream/FbiManualOfInvestigativeOperationsAndGuidelines-Updates/FBI-MIOGUpdates1_djvu.txt ("These guidelines on the use of informants and confidential sources are set forth solely for the purpose of internal Department of Justice guidance. They are not intended to, do not, and may not be relied upon to create any new rights, substantive or procedural, enforceable at law by any party in any manner, civil or criminal, nor do they place any limitations on otherwise lawful investigative and litigative prerogatives of the Department of Justice.”).

165. Schreiber, supra note 39, at 341-42.

166. Id.

167. INSPECTOR GEN. COMPLIANCE STUDY, supra note 45, at 3.

168. Id. at 7. 
Immigration rewards appear only once in the Guidelines, yet this single reference exemplifies the impunity with which law enforcement procures informants. The Guidelines state that "[n]o promises or commitments can be made, except by the United States Department of Homeland Security, regarding the alien status of any person or the right of any person to enter or remain in the United States.”169 The Guidelines also note that informants should receive this information if and when they have any issues regarding immigration status. ${ }^{170}$

While acknowledging that FBI agents may only offer immigration benefits to informants pursuant to DHS's agreement, the Guidelines do not answer the questions raised by this arrangement. Unlike monetary rewards, for which the Guidelines establish a number of rules regarding proper payment procedures and conditions, ${ }^{171}$ it is not clear under what circumstances immigration rewards must be documented and whether they are subject to conditions similar to those of monetary rewards. Their brief appearance in the Guidelines shows the FBI's recognition of immigration benefits as a method to elicit informant cooperation, but details on their use are nonexistent. This absence of information indicates that agents may possess vast discretion when using immigration rewards to recruit informants. It also indicates that executing these rewards is ultimately in the hands of DHS.

\section{B. Constitutional Limitations}

In theory, both the Fourth Amendment and the Due Process Clause of the Fifth Amendment restrict the FBI's use of informants in terrorism investigations. However, neither Amendment has actually limited the Agency's recruitment tactics when dealing with subjects facing immigration-related pressures to serve as informants.

The Fourth Amendment's prohibition against unreasonable searches and seizures $^{172}$ does not offer any substantive restrictions on the FBI's use of informants in terrorist investigations. In criminal investigations where the Fourth Amendment does apply, it places few restrictions on the use of information gathered by informants. ${ }^{173}$ To obtain a warrant based on intelligence gathered by an informant, the information must be reliable in establishing the requisite probable cause. ${ }^{174}$ In matters of national security however, the search standard is less stringent than the probable cause standard

169. ATTORNEY GEN. CONFIDENTIAL SOURCES GUIDELINES, supra note 157, at 16.

170. Id.

171. Id. at 28. The Guidelines contain rules prohibiting contingent payments, approval for payments, documentation of payments, accounting and reconciliation procedures, and coordination with prosecution.

172. U.S. CONST. amend. IV ("The right of the people to be secure in their persons, houses, papers, and effects, against unreasonable searches and seizures, shall not be violated.”).

173. See Illinois v. Gates, 462 U.S. 213 (1983); Aguilar v. Texas, 378 U.S. 108, 114 (1964).

174. Aguilar, 378 U.S. at 114. 
used in criminal investigations. ${ }^{175}$ In fact, the United States Supreme Court has never held that the Fourth Amendment applies to national security investigations. ${ }^{176}$ In particular, the Foreign Intelligence Surveillance Act of 1978 (FISA) $^{177}$ shields federal agents from standard criminal warrant requirements when carrying out electronic surveillance and searches. The Foreign Intelligence Surveillance Court, a secret court ${ }^{178}$ created by FISA to issue warrants in national security investigations, ${ }^{179}$ only requires probable cause that "the target of the electronic surveillance is a foreign power or an agent of a foreign power." 180 Hence, because agents do not have to produce evidence of criminal activity before initiating electronic or physical surveillance, they are able to use informants more freely. ${ }^{181}$ Under FISA, the Attorney General can also authorize surveillance for up to a year without court order. $^{182}$

Furthermore, in 1982, President Reagan's Executive Order No. 12,333 identified the FBI as the primary gatherer of domestic intelligence and held that the Attorney General holds the power to carry out warrantless searches and surveil agents of foreign powers. ${ }^{183}$ Executive Order No. 12,333 essentially paved the way for the FBI's use of informants to conduct domestic surveillance of foreign agents, including members of foreign terrorist organizations, without

175. Moreover, it is unclear whether the Fourth Amendment applies to nondomestic national security investigations. United States v. U.S. Dist. Ct., 407 U.S. 297, 308-09 (1972); United States v. Truong Dinh Hung, 629 F.2d 908, 914-16 (4th Cir. 1980).

176. The Fourth Circuit found that surveillance directed toward foreign intelligence does not fall within Fourth Amendment protection. Truong Dinh Hung, 629 F.2d at 913, 914 ("More importantly, the executive possesses unparalleled expertise to make the decision whether to conduct foreign intelligence surveillance, whereas the judiciary is largely inexperienced in making the delicate and complex decisions that lie behind foreign intelligence surveillance .... [B]ecause of the need of the executive branch for flexibility, its practical experience, and its constitutional competence, the courts should not require the executive to secure a warrant each time it conducts foreign intelligence surveillance.”).

177. Foreign Intelligence Surveillance Act of 1978, Pub. L. No. 95-511, 92 Stat. 1783 (1978) (codified as amended at 18 U.S.C. §§ 2511, 2518, 2519, 50 U.S.C. §§ 1801-11, 1821-29, 1841-46, 1861-62, 1871 (2000 \& Supp. III 2003)), amended by Intelligence Reform and Terrorism Prevention Act of 2004, Pub. L. No. 108-458, 118 Stat. 3638 (2004).

178. The Foreign Intelligence Surveillance Court, or FISC, consists of eleven federal district judges. Most of the court's opinions and filings are classified. FISC decisions are reviewable by the Foreign Intelligence Surveillance Court of Review (FISCR) and the Supreme Court, although since FISCR was established in 1978 it did not meet to review a case until 2002. Electronic Privacy Information Center, Foreign Intelligence Surveillance Court (FISC), http://epic.org/privacy/terrorism/ fisa/fisc.html (last visited Oct. 18, 2013).

179. 50 U.S.C. $\S 1803$ (a) (2012).

180. 50 U.S.C. $\S 1805(a)(1)(A)$.

181. Ward, supra note 45, at 630-33. The Second Circuit has upheld FISA's warrant procedures. United States v. Duggan, 743 F.2d 59, 71-76 (2d Cir. 1984). In addition, the Northern District of Illinois has upheld warrantless physical search procedures under FISA as a foreign intelligence exception to the Fourth Amendment. United States v. Marzook, 435 F. Supp. 2d 778 (N.D. Ill. 2006).

182. 50 U.S.C. $\S 1802$.

183. Exec. Order No. 12,333, § 2.5, 3 C.F.R. 200, 212 (1982). 
adhering to the restrictions inherent in the use of informants in domestic criminal investigations. In domestic criminal investigations, agents are required by law to corroborate informants' intelligence and credibility before a warrant is issued. ${ }^{184}$ However, under Executive Order No. 12,333, this corroboration is not required in terrorism investigations. ${ }^{185}$ For informants facing deportation and immense pressure to cooperate, these lax warrant requirements remove an important check on the validity of their intelligence. The requirements also give the FBI more opportunities to abuse its power. Although no court has explicitly found Executive Order No. 12,333 constitutional, no court has found it unconstitutional and thus it remains good law. Indeed, the Northern District of Illinois found that FBI reliance on the Order in conducting physical searches for foreign intelligence gathering was reasonable. ${ }^{186}$

The Due Process Clause of the Fifth Amendment has provided a way to avoid deportation to some informants facing deportation under the state-created danger doctrine. ${ }^{187}$ The doctrine allows for recovery and injunctive relief for civil rights violations. It holds that "the government has a constitutional duty to protect a person against injuries inflicted by a third-party when it affirmatively places the person in a position of danger the person would not otherwise have faced." "188 To establish a successful claim under this doctrine, a valid relationship must have existed between the plaintiff and state; the state must have created the opportunity that ultimately harmed the plaintiff; the state must have acted in willful disregard for the plaintiff's safety; and the harm must have been foreseeable. ${ }^{189}$ Notably, given its nearly exclusive use in domestic criminal cases, ${ }^{190}$ the state-created danger doctrine has limited use for immigrant informants.

The First and Third Circuits have declined to apply the danger doctrine in deportation cases because it intrudes on Congress's plenary power over immigration. ${ }^{191}$ The Fifth and Ninth Circuits, however, have left the doctrine

184. See Illinois v. Gates, 462 U.S. 213, 238 (1983) (holding that in order to find probable cause to issue a warrant, courts must assess the informant's credibility, reliability, and basis of knowledge in totality).

185. Ward, supra note 45 , at 642-43.

186. Marzook, 435 F. Supp. 2d at 791.

187. U.S. CONST. amend. V; Rosciano v. Sonchik, No. CIV-01-472-PHX-FJM, 2002 U.S. Dist. LEXIS 25419 (D. Ariz. Sept. 10, 2002).

188. Kamara v. Attorney Gen., 420 F.3d 202, 216 (3d Cir. 2005); see also Enwonwu v. Gonzales, 438 F.3d 22, 29-30 (1st Cir. 2006).

189. Kamara, 420 F.3d at 216.

190. See, e.g., Kennedy v. City of Ridgefield, 439 F.3d 1055, 1062 (9th Cir. 2006); Pena v. DePrisco, 432 F.3d 98, 108-09 (2d Cir. 2005) (applying the state-created danger doctrine to a murder case and drunk driving death case, respectively); Forrester v. Bass, 397 F.3d 1047, 1057-59 (8th Cir. 2005) (recognizing the state-created danger doctrine in a child abuse case); Butera v. District of Columbia, 235 F.3d 637, 647-51 (D.C. Cir. 2001) (recognizing the danger doctrine in the death of an undercover police officer).

191. Kamara, 420 F.3d at 217; Enwonwu, 438 F.3d at 30. 
open for potential use by immigrant informants. ${ }^{192}$ Nevertheless, even if the danger doctrine was applied in immigration cases, many of the terrorism informants in the United States lack ties to actual terrorist groups in or outside of the United States ${ }^{193}$ and thus are not subject to threat of retaliation from actual terrorist groups if deported. Hence, the state-created danger doctrine may not help many terrorism informants avoid deportation.

Additionally, the state-created danger theory only protects informants after recruitment, and provides no benefits to informants when negotiating the terms of their agreement with the FBI. While the knowledge that informants can later enforce their agreements may encourage more careful engagement with potential informants, ultimately bolstering informants' ability to vindicate their agreements with the government, the danger theory creates no incentive for the FBI to only recruit informants with established ties to terrorist organizations. In fact, because the danger doctrine is likely only useful when informants have preexisting ties to terrorist organizations, the doctrine may steer the FBI away from recruiting those with established ties because doing so would provide these informants with a way to enforce their agreements. Nevertheless, until courts actually extend the danger doctrine to deportation cases, the protective value of this theory is unknown.

\section{Entrapment Defense and Outrageous Government Conduct Doctrine}

The entrapment defense and the claim of outrageous government conduct are also possible sources of restriction on the FBI's use of informants. ${ }^{194}$ These protect defendants who claim to lack the necessary predisposition for criminal activity but whom the government induced to commit criminal acts. ${ }^{195}$

The test for entrapment used by most jurisdictions including the federal courts places the burden on defendants to show lack of predisposition to commit the alleged crimes. ${ }^{196}$ The entrapment defense succeeds when "the criminal design originates with the officials of the Government, and they

192. See Rosciano, 2002 U.S. Dist. LEXIS 25419, at *1 (recognizing the danger doctrine in a deportation case); Guerra v. Gonzales, 138 F. App’x 697, 699 (5th Cir. 2005) (leaving open the possibility of applying the danger doctrine to immigration cases).

193. Pat McDonnell Twair, Their American Dream Became a Nightmare, MidDLE E. CURRENT AFFS., June 2005, at 28 (Mohammad Mirmehdi was offered a "special visa" to stay in the United States for providing the FBI with Mujahedeen-e Khalq member names. Before the Mujahedeen-e Khalq was designated a terrorist organization, Mirmehdhi had attended a rally sponsored by it in opposition of the Iranian regime. Mirmedhi's only connection to the group was his attendance at the rally.); Kaye, supra note 10; Sheridan, supra note 24 (detailing examples where FBI agents used immigration violations as leverage to recruit individuals without ties to terrorist organizations).

194. The entrapment defense was first approved by the Supreme Court in Sorrells v. United States, 287 U.S. 435 (1932); the outrageous government conduct defense was first discussed in United States v. Russell, 411 U.S. 423, 431-32 (1973).

195. Russell, 411 U.S. at 429.

196. Id. at 433. 
implant in the mind of an innocent person the disposition to commit the alleged offense and induce its commission in order that they may prosecute." 197 The mere provision of materials and opportunities by the government for the commission of a crime is not sufficient unless the government's action "actually implants the criminal design in the mind of the defendant."198

In contrast, outrageous government conduct claims focus on government action. In United States v. Russell, the Supreme Court acknowledged that "we may some day be presented with a situation in which the conduct of law enforcement agents is so outrageous that due process principles would absolutely bar the government from invoking judicial processes to obtain a conviction." ${ }^{199}$ Unlike entrapment, outrageous government conduct is not an affirmative defense. Rather, it seeks dismissal based on government violation of due process. ${ }^{200}$ To prevail, an individual must show that the government's conduct offended "fundamental fairness" and shocked "the universal sense of justice." 201 A court has never found outrageous government conduct where defendants were predisposed to commit crimes by the acts of an informant. ${ }^{202}$

The use of the entrapment or outrageous government conduct defense may raise questions about the behavior of the informant and the government agent's instructions to the informant. While the entrapment defense may allow a defendant to escape criminal liability, an examination of government relations with informants may call for public and political limitations on the FBI's dealings with informants. ${ }^{203}$ Usually, because law enforcement values the secrecy of its dealings with informants, evidence about informant recruitment and handling only surfaces after egregious cases involving informants acting as agent provocateurs. ${ }^{204}$ For example, in Cromitie, the defendant argued that the government entrapped and subjected him to outrageous conduct. ${ }^{205}$ Although neither claim ultimately prevailed, Cromitie exposes how far the government may go to set up an individual for a crime, including offering a car and a quarter million dollars to participate in terrorist acts. ${ }^{206}$

Cases like Cromitie do little to restrict the FBI's dealings with informants. If courts were more receptive to claims of entrapment and outrageous

197. Id. at 434-35 (quoting Sorrells, 287 U.S. at 442).

198. Id. at 436 .

199. Id. at 431-32.

200. Id.

201. Id. at 432.

202. See, e.g., United States v. Pedraza, 27 F.3d 1515, 1521 (10th Cir. 1994) (holding that infiltrating an ongoing criminal enterprise, or inducing a defendant to repeat, continue, or expand criminal activity does not constitute outrageous government conduct).

203. See, e.g., United States v. Salemme, 91 F. Supp. 2d 141 (D. Mass. 1999) (the case of Boston gangsters Steven Flemmi and Whitey Bulger), rev'd in part sub nom. United States v. Flemmi, 225 F.3d 78 (1st Cir. 2000).

204. Schreiber, supra note 39, at 352 n.301.

205. 781 F. Supp. 2d 211, 213-14 (S.D.N.Y. 2011).

206. Id. at 218-21. 
government conduct, law enforcement agencies would be threatened by the risk of exposure, which in turn might encourage them to curtail their aggressive tactics. Nevertheless, most terrorism investigations and cases involving terrorist defendants never go to trial, making Cromitie an unusual case. ${ }^{207}$ In terrorism cases, defendants must overcome an unusually heavy burden because irrespective of the government's conduct or the defendant's vulnerability, committing or assisting in the commission of terrorist acts is always considered evidence of a predisposition to terrorism. ${ }^{208}$ Cromitie demonstrates that even though courts acknowledge the government's outrageous conduct, courts may nevertheless find that a defendant's agreement to participate in terrorist acts demonstrates the necessary predisposition. ${ }^{209}$ The fact that the FBI suffered no repercussions for aggressively recruiting Cromitie shows that entrapment and outrageous government conduct claims effectively do not restrain the FBI's use of aggressive terrorism informant recruitment tactics.

\section{Nondeportation Agreements in Plea Bargains}

Nondeportation agreements have also failed to effectively restrain the FBI's use of informants via immigration law. In the United States, most criminal cases are resolved by plea bargains. ${ }^{210}$ Before the 1970 s, plea bargaining was conducted in relative secrecy and deals between the parties were not recorded. ${ }^{211}$ In the 1970s, the Supreme Court held that if prosecutors

207. In fact, most of these cases settle before reaching trial. See Said, supra note 21, at 715 (detailing trials that led to convictions). For an example of a failed attempt at using the entrapment defense in a terrorism cases, see United States v. Lakhani, 480 F.3d 171, 174 (3d Cir. 2007); NYU SChOOl of LaW, Ctr. on LaW and SeC., Terrorist Trial Report Card: SEPTEMBer 11, 2001SEPTEMBER 11, 2011, at 12 (2011), available at http://www.lawandsecurity.org/Portals/0/Documents/ TTRC\%20Ten\%20Year\%20Issue.pdf (Of 376 terrorism cases resulting in convictions, only 90 went to trial while 286, or 66.4 percent, were resolved by guilty pleas. Out of the 431 cases reviewed, only 55, or 12.8 percent, did not lead to convictions); Karen Greenberg, How Terrorist 'Entrapment' Ensnares Us All, THE GUARDIAN (Dec. 12, 2011, 12:45 PM), http://www.theguardian.com /commentisfree/cifamerica/ 2011/dec/12/how-terrorist-entrapment-ensares-us-all (noting that no defendant who has claimed entrapment in a terrorism prosecution after 9/11 has succeeded); Entrapment Defense Hasn't Worked in Terror Cases, NPR (Dec. 2, 2010, 1:00 PM), http://www.npr.org/2010/12/02/131758291/ entrapment-defense-hasn-t-worked-in-terror-cases.

208. Greenberg, supra note 207 ("[I]f the government can show that the defendant was inclined to the crime, then the entrapment-by-inducement defense cannot prevail in court. In a terrorism case, the fact of being willing to commit an act of terrorism is seen as predisposition, no matter how much of a Catch-22 this may be. As a result, lawyers rarely choose to mount the defense.”).

209. 781 F. Supp. 2d 211.

210. Lindsey DeVERs, BuREAu of Justice Assistance, U.S. DeP'T OF Justice, Plea AND Charge Bargaining 3 (2011), available at https://www.bja.gov/Publications/PleaBargaining ResearchSummary.pdf (stating that 90-95 percent of cases result in plea bargains).

211. See Blackledge v. Allison, 431 U.S. 63, 76-77 (1977) (describing the secrecy surrounding plea bargaining and the lack of recording); 27 AM. JUR. PROOF OF FACTS 2D 133. 
reneged on plea bargains, petitioners were entitled to specific performance, resentencing, or withdrawal of the guilty plea. ${ }^{212}$

Traditionally, courts have treated nondeportation agreements and plea bargains as contracts. ${ }^{213}$ Thus, when the prosecution does not follow through with the promised benefits of a plea agreement, defendants may enforce the agreement as though it were a contract. ${ }^{214}$ Further, nondeportation agreements are similar to plea bargains in that the defendant agrees with the government to some detriment in exchange for a benefit. Due to these similarities, until the 1990s the Eighth and Ninth Circuits routinely enforced plea bargains when informants were promised immigration benefits in exchange for information. ${ }^{215}$

In addition to the standard contract elements of offer, acceptance, and consideration, two additional elements must have been present in the agreement in order to establish an enforceable claim against the government. First, the government agent must have had "actual authority" to ensure government performance. ${ }^{216}$ Second, agency principles must have been present in the agreement. Agency is present when one person, namely the agent, consensually acts on behalf of another-the principal. ${ }^{217}$ Hence, an agreement entered into by the prosecutor, as the agent, creates a contract between the principal (the immigration official) and the third party (the informant). ${ }^{218}$

Nevertheless, in 1996 the Department of Justice issued regulation 28 C.F.R. § 0.197 which stated that immigration officials could not be held responsible for prosecution-made plea agreements in criminal proceedings or investigations that involved immigration laws. ${ }^{219}$ Further, in order for agreements to count under 28 C.F.R. § 0.197, there must be written authorization from DHS.

Cases that have addressed 28 C.F.R. § 0.197 since its enactment have affirmed it. For instance, in Bao Tai Nian v. Holder, the Ninth Circuit affirmed

212. See Santobello v. New York, 404 U.S. 257, 263 (1971) (remanding the petitioner's case); Blackledge, 431 U.S. at 79 (holding petitioner was entitled to an evidentiary hearing to determine whether parties created an enforceable plea bargain).

213. See, e.g., Dowell v. United States, 694 F.3d 898, 902 (7th Cir. 2012) (treating plea agreement as a contract); United States v. Leniear, 574 F.3d 668, 672 (9th Cir. 2009) (using contract law principles to analyze defendant's breach of nondeportation agreement); United States v. Castaneda, 162 F.3d 832, 836-37 (5th Cir. 1998) (same).

214. Dowell, 694 F.3d at 902.

215. See Thomas v. INS, 35 F.3d 1332 (9th Cir. 1994) (holding that immigration officials were bound by plea bargains); Margalli-Olvera v. INS, 43 F.3d 345 (8th Cir. 1994) (holding that the Assistant United States Attorney had the power to bind immigration officials).

216. Fed. Crop Ins. Corp. v. Merrill, 332 U.S. 380, 384 (1947).

217. RESTATEMENT (THIRD) OF AGENCY §§ 1.01, 1.03 (2006).

218. See id. § $6.01 \mathrm{cmt}$. a.

219. 28 C.F.R. § 0.197 (1996) ("The Immigration and Naturalization Service (Service) shall not be bound, in the exercise of its authority under the immigration laws, through plea agreements, cooperation agreements, or other agreements with or for the benefit of alien defendants, witnesses, or informants, or other aliens cooperating with the United States Government, except by the authorization of the Commissioner of the Service or the Commissioner's delegate.”). 
petitioner's deportation and held that a letter from an Assistant United States Attorney presumably promising nondeportation had no bearing on the case because according to existing regulation, "absent written authorization from the Commissioner of the Immigration and Naturalization Service ('INS'), the INS shall not be bound by cooperation agreements that government agencies may reach with alien witnesses." 220 Similarly, in Frimpong v. Holder, petitioner alleged that a federal prosecutor had promised him relief from deportation in exchange for information against petitioner's coconspirators. ${ }^{221}$ There, the court dismissed his argument because there was no evidence of written authorization from DHS for the agreement, as required by the regulation. ${ }^{222}$ Effectively, unless authorized by DHS, an FBI offer of nondeportation as an incentive does not bind the FBI to performance.

Considering the Guidelines, various constitutional limits, the entrapment defense, and the near complete unenforceability of nondeportation agreements, the FBI has great discretion and little potential liability when recruiting informants. Very little prevents the FBI from pursuing aggressive recruiting tactics like probing an individual's background for immigration violations and using these as ways to elicit cooperation. Once the informant cooperates, almost nothing prevents the FBI from disregarding the promise of immigration benefits. Today, nothing adequately restrains the FBI's recruitment practices, leaving informants particularly vulnerable to coercion and thus more likely to provide faulty information.

IV.

A Possible Solution: THE S-6 VISA

As it currently exists, the S-6 visa may be a way of controlling the FBIinformant relationship in cases involving promised immigration benefits. The S-6 visa rewards terrorism informants with permanent residency status. However, as discussed infra, in order for the S-6 visa to effectively restrain the FBI and produce useful intelligence, the S-6 visa needs to be modified.

The examples discussed supra in Part II illustrate how the overbroad and indiscriminate use of informants, particularly those recruited with immigration threats or rewards, harms the acquisition of useful information, fails to identify and protect against legitimate threats, chills speech, and encourages ethnic and religious profiling. Immigration law offers less protection to informants than promises of leniency in criminal matters, thus increasing the potential for informants to produce faulty intelligence. Part III, supra, demonstrates that limitations on FBI dealings with informants are practically nonexistent.

This Part proposes a revision to the S-6 visa that would help diminish the harmful effects discussed in Part II by increasing transparency and providing

220. Bao Tai Nian v. Holder, 479 F. App’x 68, 69 n.2 (9th Cir. 2012).

221. Frimpong v. Holder, 355 F. App’x 63, 64 (7th Cir. 2009).

222. Id. 
more procedure for FBI informant recruitment via immigration law. Specifically, providing immigrant informants with better bargaining power and ways to vindicate their agreements through the S-6 visa would alleviate some of the aforementioned harms.

Although there have been few reports of the FBI abandoning immigration promises in counterterrorism investigations, ${ }^{223}$ the FBI has repeatedly broken alleged immigration and monetary ${ }^{224}$ promises made to informants in exchange for participation in drug investigations, ${ }^{225}$ human trafficking investigations, ${ }^{226}$ and pre-9/11 terrorism prosecutions. ${ }^{227}$ Providing a more straightforward and transparent way for the FBI to offer immigration benefits to informants would help decrease informants' potential vulnerability and limit the FBI's power. With modifications, the S-6 visa could help resolve these problems.

\section{A. The Current S-6 Visa Requirements}

Established in 1994 as part of the Violent Crime Control and Law Enforcement Act, the S-6 visa, or "snitch visa," 228 rewards terrorism informants and their families with legal permanent residence. ${ }^{229}$ More specifically, the Act allows the government to give a temporary (three-year) material witness visa to people with probative knowledge of criminal activity. ${ }^{230}$ During this three-year stay, an S-6 visa recipient can apply for permanent resident status, or a "green card," which may subsequently permit the recipient to apply for citizenship. ${ }^{231}$

S-6 visas are subject to a different allotment system than immigrant-type visas. $^{232}$ Specifically, Congress allots fifty S-6 visas each year, and unused visas cannot be carried forward. ${ }^{233}$ Furthermore, respective family members

223. For one such case, see Werner, supra note 28.

224. Caryle Murphy \& Del Quentin Wilber, Terror Informant Ignites Himself near White House, WASH. POST, Nov. 16, 2004, at A1.

225. See Becker, supra note 28; see also Morgan v. Gonzales, 495 F.3d 1084 (9th Cir. 2007) (enforcing removal proceedings against an informant who agreed to testify against drug dealers in exchange for permanent residency).

226. Helen O’Neill, Emilio Maya, Sister Analia Face Deportation After Helping Immigration and Customs Enforcement Agency, THE HufFington POsT (Feb. 13, 2010, 2:51 PM), http://www.huffingtonpost.com/2010/02/15/emilio-maya-sister-analia_n_462968.html.

227. See, e.g., Awad v. United States, 301 F.3d 1367 (Fed. Cir. 2002).

228. Nora V. Demleitner, Immigration Threats and Rewards: Effective Law Enforcement Tools in the "War" on Terrorism?, 51 EMORY L.J. 1059, 1078 (2002).

229. Id.; 8 U.S.C. § 1184(k)(1) (2012).

230. 8 U.S.C. $\S 1184(\mathrm{k})(1)$.

231. Green Card (Permanent Residence), U.S. CITIZENSHIP AND IMMIGRATION SERVS., http:/www.uscis.gov/portal/site/uscis/menuitem.eb1d4c2a3e5b9ac89243c6a7543f6d1a/?vgnextoid=ae 853ad15c673210VgnVCM100000082ca60aRCRD\&vgnextchannel=ae853ad15c673210VgnVCM100 000082ca60aRCRD (last updated May 13, 2011).

232. ESTER, supra note 33.

233. Criminal Resource Manual, 1862 S Visa Program—Eligibility, U.S. DEP’T OF JUSTICE, http:/www.justice.gov/usao/eousa/foia_reading_room/usam/title9/crm01862.htm (last updated July 2011) [hereinafter 1862 S Visa Eligibility]. 
who are also eligible to come to the United States do not count toward the allotment. ${ }^{234}$ To qualify for the S-6 visa, however, those providing critical and reliable information necessary for the successful investigation or prosecution of terrorist organizations ${ }^{235}$ must be in danger of retaliation in their home country, and qualify for a reward under the State Department's Rewards for Justice Program. ${ }^{236}$

The State Department's Rewards for Justice program was established in 1984 under the Act to Combat International Terrorism. ${ }^{237}$ At the discretion of the Attorney General, the Program provides rewards of up to $\$ 500,000$ to "any individual who furnishes information leading to the arrest or conviction, in any country, of any individual or individuals for the commission of [or conspiracy to commit] an act of terrorism against a United States person or United States property."238

Individuals cannot apply for the S-6 visa on their own behalf; only state or federal law enforcement agencies may apply on behalf of an individual. ${ }^{239}$ Individuals eligible for immigration benefits under the S-6 visa program would generally be inadmissible in the United States or otherwise subject to deportation due to criminal or immigration status violations. ${ }^{240}$ As part of the process, applicants must waive their rights to any deportation hearings and appeals should deportation proceedings occur ${ }^{241}$-further eroding their bargaining power-and must acknowledge that the S-6 visa is the sole authorization of their presence in the United States. ${ }^{242}$ In turn, the United States Attorney with jurisdiction over the investigation that forms the basis for the request must certify that no promises regarding immigration benefits have been or will be made to applicants. ${ }^{243}$ Furthermore, law enforcement agencies initiating the requests must provide affidavits, statements, or other evidence demonstrating applicants' cooperation, their grounds for exclusion, and the government's need for the terrorism intelligence. ${ }^{244}$ Law enforcement agencies must then file this information with the Assistant Attorney General in the Criminal Division of the Department of Justice. ${ }^{245}$

234. Id.

235. Id.

236. Id.

237. 1984 Act to Combat International Terrorism, Pub. L No. 98-533, 98 Stat. 2706 (codified at 18 U.S.C. § $3071-77$ (2002)).

238. Id.

239. 8 C.F.R. § 214.2(t)(4) (2011).

240. 1862 S Visa Eligibility, supra note 233.

241. 8 C.F.R § 214.2(t)(2); Criminal Resource Manual 1863 S Visa Program-Application Procedures, U.S. DEP'T OF JUSTICE [hereinafter 1863 S Visa Procedures], http://www.justice.gov/usao /eousa/foia_reading_room/usam/title9/crm01863.htm (last updated July 2011).

242. $\S 214.2(\mathrm{t})(4)(\mathrm{i})$.

243. $\S 214.2(\mathrm{t})(4)(\mathrm{i})(\mathrm{B})$.

244. $\S 214.2(\mathrm{t})(4)(\mathrm{i})(\mathrm{C})$.

245. $\S 214.2(\mathrm{t})(4)(\mathrm{i})(\mathrm{D})$. 
Upon reaching the Assistant Attorney General, the information is reviewed for accuracy and specific factors are weighed to determine eligibility for the S-6 visa. ${ }^{246}$ When necessary, "representatives of the [Immigration and Naturalization] Service [(now the U.S. Citizenship and Immigration Services (“USCIS”))], Marshals Service, Federal Bureau of Investigation, Drug Enforcement Administration, Criminal Division, and the Department of State, and those representatives of other [law enforcement agencies], including state and federal courts designated by the Attorney General" are involved in the review process to determine which cases should receive priority. ${ }^{247}$ Once the Attorney General approves the application and the Secretary of State certifies it, the application proceeds to the Immigration and Naturalization Services Commissioner (now the USCIS Director) ${ }^{248}$ for final approval. ${ }^{249}$ After notification is obtained from USCIS, the Assistant Attorney General may object to the decision within seven days, in which case the Deputy Attorney General makes a final decision. ${ }^{250}$ Nevertheless, under no circumstances can law enforcement agencies and applicants appeal the decision. ${ }^{251}$ During the time the informant works with the law enforcement agency, he or she must report to the agency on a quarterly basis, and the agency must report to the Assistant Attorney General in the Criminal Division. Finally, the Assistant Attorney General and the USCIS Director must together make an annual report to the Committee on the Judiciary of the House of Representatives and the Committee on the Judiciary of the Senate.

Reports indicate that no S-6 visas were issued to terrorism informants between 1994 and 2006. ${ }^{252}$ There is also no indication of how many S-6 visas, if any, were processed during this time. The lack of incentives for the FBI to apply for S-6 visas on behalf of informants may be responsible for this. That is, while the prospect of legal permanent residency may be tempting bait for the FBI to dangle in front of potential informants, the bureaucratic process involved in obtaining an S-6 visa is discouraging. ${ }^{253}$ Hence, while the FBI may tout S-6 visas to potential informants, the use of coercive and unapproved

246. $\S 214.2(\mathrm{t})(4)(\mathrm{ii})(\mathrm{A})$.

247. $\S 214.2(\mathrm{t})(4)(\mathrm{ii})(\mathrm{B})$.

248. $\S \S 214.2(\mathrm{t})(2), 214.2(\mathrm{t})(4)(2)(\mathrm{D})$.

249. $\S 214.2(\mathrm{t})(5)(\mathrm{i})$.

250. § 214.2(t)(5)(iii).

251. Id.

252. Letter to Tegan Millspaw, Judicial Watch, from Katherine L. Myrick, Chief, Operations Unit, FOI/Records Management Section, U.S. DEP'T OF JUSTICE, Issuance and Distribution of S-5 and S-6 Visas (Aug. 18, 2008) at 26. EsTER, supra note 33. Limited data regarding the use of S visas is available, but in 2007, U.S. Immigration and Customs Enforcement reported that $139 \mathrm{~S}$ visas were processed and 80 approved. Between 2004 and 2007, the highest number of S visas approved in a year was 94, with the lowest being 78. The data does not distinguish between S-6 visas given for terrorist information versus S-5 visas given for other criminal information, but the available report states that no S-6 visas were issued to terrorism informants between 1994 and 2006. Id.

253. 8 C.F.R. § 214.2(t) (2011). 
threats of deportation is more likely to result in cooperation-with less time, effort, and oversight. Since informants waive their recourses in S-6 visa agreements, the FBI suffers no legal backlash when it fails to fulfill promises made to them. ${ }^{254}$ Essentially, the potential benefits of using the S-6 visa are outweighed by the lengthy process involved, especially if the FBI can circumvent the process or break its promises. In the end, the FBI has no real reason to seek an S-6 visa for an informant.

\section{B. Proposed Modifications to the S-6 Visa}

Greater use of the S-6 visa would ensure judicial review of government practices by forcing the FBI to be more careful about following procedures in recruiting and dealing with informants. Changes to the S-6 visa program that provides material witness visas to informants with intelligence about terrorist activities could formalize the use of immigration rewards for terrorism intelligence in ways that would benefit the FBI and potential informants, and could help reduce the unnecessary and harmful surveillance of Muslim and Middle Eastern communities. In order for the S-6 visa to become a useful tool for the FBI without compromising civil liberties, the S-6 visa must be more readily available, easier to grant, and carefully tailored.

The low numbers of S-6 visas used by law enforcement agencies may indicate several potential problems with the program. It may seem paradoxical to suggest that the available number of S-6 visas is too low when congressional reports reveal no S-6 visas were issued between 1994 and 2006. ${ }^{255}$ However, these low numbers likely reveal more about the drawbacks of the S-6 visa program than they do about the value of immigration incentives as an intelligence tool. In particular, the inconveniences the S-6 visa application process imposes are barriers to efficient and productive use of the S-6 visa program.

If FBI informants number in the thousands, as reports suggest, ${ }^{256}$ and the FBI continues to make terrorism prevention a priority, then it seems Congress has failed to offer an appropriate number of S-6 visas for counterterrorism investigations. Whether or not the current number of informants in use is necessary for effective terrorism prevention is outside the scope of this Comment. Nevertheless, the current allotment of fifty S-6 visas per year seems low when compared to the premium the FBI places on terrorism investigation and prevention and the estimated fifteen thousand informants in use. ${ }^{257}$ Although not all of these informants work on terrorism-related investigations, it

254. 1863 S Visa Procedures, supra note 241.

255. See ESTER, supra note 33, at 2.

256. The Informants, supra note 8 (reporting around 15,000 informants).

257. Id.; What We Investigate, FED. BUREAU OF INVESTIGATION, http://www.fbi.gov/aboutus/investigate (last visited Oct. 18, 2013) (listing terrorism as number one under National Security Priorities). 
is reasonable to assume that since terrorism prevention tops the list of FBI priorities, ${ }^{258}$ there are more than fifty of them that do. If Congress truly intends the S-6 visa to become a viable instrument in fighting the war on terror, it must give the FBI the appropriate tools — and number of tools - to work with.

In determining a useful and appropriate number of S-6 visas to allot, under this proposal Congress would also be forced to determine the number of terrorism informants in use and whether the FBI plans to reward these individuals with S-6 visas for themselves and their families. Furthermore, were a court to find that the FBI cannot bypass the S-6 visa process, and modify the eligibility requirements, the number of S-6 visas would likely rise. In sum, increasing ${ }^{259}$ the statutory allotment of S-6 visas could ensure that there are enough S-6 visas available to cover the increased number of terrorism informants employed by the FBI.

S-6 visa eligibility requirements also lack the proper tailoring to allow the FBI to make use of them while still guarding against overbroad informant recruitment and use which leads to religious and ethnic profiling. Changing the eligibility standards could better protect informants and produce more reliable intelligence for the FBI. For example, one potential change would do away with requiring informants to also be eligible for the State Department's Rewards for Justice Program established by the Act to Combat International Terrorism. ${ }^{260}$ As previously mentioned, the Act gives the Secretary of State sole discretion to monetarily reward individuals who provide information leading to the arrest or conviction of anyone committing or conspiring to commit international terrorism against the United States. ${ }^{261}$ Those who frustrate acts of terrorism or dismantle terrorist organizations are also covered by the Act. ${ }^{262}$

In short, the Rewards for Justice Program eligibility requirements are quite high. Many informants may have useful terrorism intelligence that may not necessarily lead to an arrest or conviction. Furthermore, both the Attorney General and the Secretary of State approve awards on a discretionary basis not subject to judicial review. ${ }^{263}$ Abolishing the requirement that an informant be eligible for a monetary reward under the Rewards for Justice Program would make S-6 visas available to more terrorism informants. While this would not

258. What We Investigate, supra note 257.

259. Although by no means a perfect way of estimating the number of S-6 visas needed, determining the number of informants hired is one potential way. See ESTER, supra note 33, at 3.

260. 8 U.S.C. § 1101 (2012); 22 U.S.C. § 2708 (2008).

261. 22 U.S.C. § 2708(b)(1)-(2). However, the Secretary of State must approve any reward of more than $\$ 100,000$, and within thirty days of payment, the Secretary must submit a report to the appropriate congressional committees detailing the amount, the significance of the information, and the acts meriting the reward. Id. at $\S \S 2708(\mathrm{e})(4)$, (g)(1).

262. Id. at §§ 2708(4)-(7).

263. Rewards for Justice, Frequently Asked Questions, U.S. DEP’T OF STATE, http://www .rewardsforjustice.net/index.cfm?page=faq\&language=english\#q1 (last visited Oct. 18, 2013). 
necessarily curtail the FBI's ethnic and religious profiling, making the visa available to more informants may encourage the FBI to actually use it, thereby creating a more legitimate and transparent path to immigration rewards than that afforded by current government practices.

Similarly, the S-6 visa requirement that informants be in danger of retaliation for providing critical and reliable intelligence ${ }^{264}$ will likely not be met when immigration benefits are the impetuses for cooperation. Because informants recruited for counterterrorism investigations often have no connection to foreign terrorist organizations, ${ }^{265}$ and are tasked with preventing "lone wolf" terrorists, they would likely not face threats from legitimate terrorist organizations if deported to their country of origin. Abolishing the "danger of retaliation" requirement would make the S-6 visa available to more informants and give them more incentive to cooperate with the FBI. It would also give the FBI greater assurance that informants' cooperation is not based on empty promises. In all, removing this requirement, along with the requirement that informants be eligible for the Rewards for Justice Program, would remove some of the barriers to receiving an S-6 visa.

To limit the religious and ethnic profiling created through the widespread use of informants, the S-6 visa should also require that informants possess critical and reliable intelligence prior to agreeing to inform. Critical and reliable information is based on preexisting ties to terrorists or terrorist organizations rather than on ethnicity or religion. In the cases at issue in this Comment, the FBI typically recruits informants without a specific surveillance target in mind. In some cases, "FBI handlers have tasked [informants] with infiltrating mosques without a specific target or 'predicate' - the term of art for the reason why someone is investigated. They were, [informants] say, directed to surveil law-abiding Americans with no indication of criminal intent."266 Informants receiving such directions from the FBI would not meet the "critical and reliable information" requirement. Hence, requiring informants to have potentially useful information that is not based purely on ethnicity or religion, but rather on preexisting ties to terrorists or terrorist organizations, would lessen the indiscriminate surveillance practices of the FBI without implementing the higher standards imposed by the Rewards for Justice Program.

Finally, individuals who agree to provide information in exchange for an S-6 visa should not be forced to waive their right to a deportation hearing. Currently, informants must knowingly waive their rights to any deportation hearings and appeals should deportation proceedings occur. They must also waive their rights to contest their detention pending deportation until lawful

264. 8 U.S.C. § 1101 (2012).

265. U.S. DEP'T OF STATE, supra note 17.

266. The Informants, supra note 8, at 36. 
permanent resident status is obtained. ${ }^{267}$ Strikingly, informants relinquish all access to judicial review if their applications are mishandled or forgotten and they subsequently face deportation. In the past, informants have alleged that the FBI has mismanaged and reneged on promises, including immigration promises. ${ }^{268}$ Allowing judicial review of the S-6 visa process would help lift the veil of secrecy under which the FBI operates. Furthermore, through redaction or other methods that preserve informants' identities, judicial review could be carried out without threatening national security. ${ }^{269}$

Another benefit of this requirement would be increased transparency in the way the FBI recruits informants. Wider use of the S-6 visa, as well as greater judicial review, would allow the government to ascertain the number of individuals enlisted by the FBI as counterterrorism informants. This may further help curb informant mishandling, a problem that plagues the agency. Because informants would still be required to provide critical and reliable intelligence, the FBI would be required to articulate clear predicates for recruiting individuals, such as a close relationship between an individual and a known member of a foreign terrorist organization. This, in turn, would provide due process and could vindicate informants' rights.

The proposed changes to the S-6 visa program would not only force the FBI to adjust its recruitment and use of counterterrorism informants, but would also help the FBI obtain more reliable and valuable intelligence while rebuilding relationships with Muslim and Middle Eastern communities. Despite the FBI's limited resources and financial limitations, the FBI and Congress should focus on finding the most accurate and efficient methods of acquiring intelligence. ${ }^{270}$ Although the FBI's budget has not suffered greatly in the financial crisis, ${ }^{271}$ the agency does have a finite amount of resources to work with. Sending unwilling informants into mosques in search of vulnerable and receptive attendees with no ties to terrorist organizations and with no independent plans to commit terrorist acts is not efficient. Requiring the FBI to only use a modified version of the S-6 visa would channel the FBI's pursuit of existing leads. In turn, the FBI's presence in mosques would decrease, which would assuage community fears. Lastly, requiring the FBI to seek informants

267. 1863 S Visa Procedures, supra note 241.

268. See, e.g., Awad v. United States, 301 F.3d 1367 (Fed. Cir. 2002) (discussing how the FBI and other federal agencies delayed informant's citizenship appliction for years).

269. For examples of methods used to keep informants' identities protected, such as redaction, privileges, and in camera review, see ETHAN WOHL, CONFIDENTIAL INFORMANTS IN PRIVATE LITIGATION: BALANCING INTERESTS IN ANONYMITY AND DISCLOSURE 14-35 (2006), available at http:/law.bepress.com/expresso/eps/1820/.

270. In fiscal year 2002, the FBI received approximately $\$ 3.5$ billion in appropriations. S. REP. No. 107-96, at 6 (2002); In contrast, in fiscal year 2012 the FBI received approximately $\$ 8.1$ billion; this was \$191.9 million above the fiscal year 2011 level. Summary of Budget Authority by Appropriation, U.S. DEP'T OF JUSTICE 1 (2013), available at www.justice.gov/jmd/2013summary/ pdf/budget-authority-appropriation.pdf.

271. Id. 
who possess reliable terrorist intelligence has the potential to reduce the possibility of informant entrapment, which would help repair the FBI's relationship with Muslim and Middle Eastern communities.

Changing the S-6 visa program and focusing on the FBI's use of immigration incentives to recruit informants may seem too narrow to appreciably influence national security and community relations. However, the point of this Comment is a narrow one: to showcase one problematic aspect in the way the FBI handles human intelligence. The recommendations here would not fully solve the problems of privacy violations, ethnic and religious profiling, and informant misuse. The use of immigration law and status to leverage informants is not the only way that the FBI recruits informants, and the S-6 visa program would likely remain relatively small even if expanded. However, as previously explained, the proposed changes to the S-6 visa would generate a more transparent system and more fruitful intelligence, and would help ensure the FBI operates within the scope of its power. Individuals pressured to provide intelligence information would have a legitimate chance to receive an S-6 visa, and the FBI would have a greater incentive to stop its overtly coercive recruitment tactics such as deportation threats.

Due to the popularity and longstanding use of informants, it is unrealistic to think that the FBI will stop using immigration law as a way to leverage cooperation. In the past, informants have aided national security by providing useful intelligence, and so they are highly valued as a source of intelligence. Hence, no matter how narrow in scope the proposed changes are, changes to the S-6 visa would greatly benefit the FBI, informants, and Muslim and Middle Eastern communities. Better intelligence may mean the difference between wasting government resources on empty threats and preventing the loss of life in future terrorist attacks.

While narrow, the proposed changes to the S-6 visa provide a promising way for expending law enforcement resources where needed, preventing manipulative informant recruitment tactics, and adding transparency to informant dealings with the FBI. Congress has the power to increase the allotment of S-6 visas and to explicitly restrict the FBI from promising immigration benefits outside of this program. The FBI should be forced to use the S-6 visa program when using immigration status as an incentive. The proposed changes would allow the FBI to use the S-6 visa as an incentive, while inhibiting its use of unnecessarily forceful tactics that lead to faulty intelligence, entrapment, and religious and ethnic profiling.

\section{CONCLUSION}

Offering S-6 visas to immigrant informants with established connections to terrorist organizations in exchange for their cooperation would be a legitimate way for the FBI to reward these informants. Further, informants would be able to rely on the FBI's promise and seek review should the 
agreement go awry. Gaining informants' trust and lessening the coercive aspect of recruitment would lead to more trustworthy intelligence, and thereby enhance national security. A larger but less committed group of informantscharacterized by the current underused S-6 visa program-does the country little good. Likewise, the indiscriminate and widespread surveillance of Muslims and Middle Easterners damages American communities and reifies assumptions and stereotypes about terrorists' identities and backgrounds. These assumptions may also blind law enforcement to real threats taking place in nonMuslim or non-Middle Eastern communities.

Expanding and modifying the use of S-6 visas would turn a small, poorly designed program into a helpful law enforcement tool that better procures reliable intelligence. Furthermore, providing more oversight for FBI informant use and restricting practices that contribute to ethnic and religious profiling would improve Muslim and Middle Eastern communities' confidence in and cooperation with the government. This, in turn, would encourage communities to effectively work with law enforcement and report suspicious activities. Information offered from within a community is more likely to be accurate, ${ }^{272}$ leading to more counterterrorism prosecutions that enhance national security and less waste of law enforcement resources on bogus threats. ${ }^{273}$

In the end, only Congress can reform the S-6 visa program to better effectuate the law's aim of rewarding informants and procuring credible intelligence on real threats. Reform would allow the FBI to more efficiently channel its resources, and would afford informants a fairer agreement—changes that would better serve the security interests of the United States.

272. Harris, supra note 23, at 133-35 (discussing how in several cases Muslim communities have alerted law enforcement to legitimate terrorist plots not created by the government).

273. More specifically, this would allow the government to dedicate resources to cases where entrapment is not at issue, or where the terrorist plot existed prior to government involvement. 